\title{
Filling Gaps in Incomplete Contracts: An Economic Theory of Default Rules
}

\author{
Ian Ayrest and Robert Gertner+†
}

\section{INTRODUCTION}

The legal rules of contracts and corporations can be divided into two distinct classes. The larger class consists of "default" rules that parties can contract around by prior agreement, while the smaller, but important, class consists of "immutable" rules that parties cannot change by contractual agreement. ${ }^{1}$ Default rules fill the gaps in incomplete contracts; they govern unless the parties contract around them. Immutable rules cannot be contracted around; they govern even if the parties attempt to contract around them. For example, under the Uniform Commercial Code (U.C.C.) the duty to act in good faith is an immutable part of any contract, ${ }^{2}$ while the warranty of merchantability is simply a default rule that parties can waive by agreement. ${ }^{3}$ Similarly, most corporate statutes

\footnotetext{
$†$ Assistant Professor, Northwestern University School of Law; Research Fellow, American Bar Foundation. B.A., Yale University; J.D., Yale Law School; Ph.D. (Economics), Massachusetts Institute of Technology. The support of Northwestern's Corporate Counsel Center is gratefully acknowledged.

It Assistant Professor, University of Chicago, Graduate School of Business. A.B., Princeton University; Ph.D. (Economics), Massachusetts Institute of Technology. The authors would like to thank Douglas Baird, Randy Barnett, Richard Craswell, John Donohue, Frank Easterbrook, Mark Grady, David Haddock, Steve Harris, Oliver Hart, Ian MacNeil, Joel Rogers, Steve Salop, David Scharfstein, David Van Zandt, Robert Vishny and seminar participants at the University of Chicago, Georgetown, Michigan, Northwestern, and Illinois law schools, and at the U.S. Department of Justice for helpful comments. Rebecca Mitchells and Jerry Richman provided excellent research assistance.

1. See B. Black, Corporate Law As Neutral Mutation, (Nov. 1988) (unpublished manuscript on file with authors) (arguing that few corporate laws are immutable). Immutable rules are similar to what Calabresi and Melamed call "inalienable" rules, Calabresi \& Melamed, Property Rules, Liability Rules, and Inalienability: One View of the Cathedral, 85 HARv. L. REv. 1089, 1093 (1972), except that immutable entitlements are created by and conditioned upon contract, while inalienable entitlements exist outside of contract. See Schwab, A Coasean Experiment on Contract Presumptions, 17 J. LEGAL STUD. 237, 239 n.6 (1988) (distinguishing between inalienable and immutable rules).

2. U.C.C. \$ 1-203 (1976); see Morin Bldg. Prod. Co. v. Baystone Constr., Inc., 717 F.2d 413, 414-15 (7th Cir. 1983); Restatement (SeCond) of Contracts $\& 205$ (1979); R. Posner, EcoNOMic Analysis of Law 81 (3d ed. 1986).

3. U.C.C. $\$ 2-314$ (1976). U.C.C. $\$ 1-102$ (1976) distinguishes between default and immutable rules and states its preference for the former:

(3) The effect of provisions of this Act may be varied by agreement, except as otherwise provided in this Act and except that the obligations of good faith, diligence, reasonableness and care prescribed by this Act may not be disclaimed by agreement but the parties may by agreement determine the standards by which the performance of such obligations is to be measured if such standards are not manifestly unreasonable.
}

(4) The presence in certain provisions of this Act of the words "unless otherwise agreed" or 
require that stockholders elect directors annually ${ }^{4}$ but allow the articles of incorporation to contract around the default rule of straight voting. ${ }^{5}$ Statutory language such as "[u]nless otherwise provided in the certificate of incorporation" or "[u]nless otherwise unambiguously indicated" makes it easy to identify statutory default, but common-law precedents can also be divided into the default and immutable camps. For example, the common-law holding of Peevyhouse v. Garland Coal $\mathbb{\Xi}$ Mining Co. ${ }^{8}$ which limited damages to diminution in value, could be contractually reversed by prospective parties. ${ }^{9}$ In contrast, the common law prerequisite of consideration is largely an immutable rule that parties cannot contractually abrogate. ${ }^{10}$

There is surprising consensus among academics at an abstract level on two normative bases for immutability. Put most simply, immutable rules are justifiable if society wants to protect (1) parties within the contract, or (2) parties outside the contract. ${ }^{11}$ The former justification turns on parentalism; the latter on externalities. Immutable rules displace freedom of contract. Immutability is justified only if unregulated contracting would be socially deleterious because parties internal or external to the contract cannot adequately protect themselves. ${ }^{12}$ With regard to immutable rules, the disagreement among academics is not over this abstract theory, but

words of similar import does not imply that the effect of other provisions may not be varied by agreement under subsection (3).

U.C.C. $\S 1-102$ (1976).

4. See, e.g., Del. Code AnN. tit. 8, § 211(c) (1974).

5. See, e.g., Del. Code ANN. tit. 8, § 214 (1974).

6. Del. Code ANN. tit. 8, \& 223 (1974).

7. U.C.C. $\$ 2-206(1976)$.

8. 382 P.2d 109 (Okla. 1962), cert. denied, 375 U.S. 906 (1963).

9. Whether the Peevyhouse majority actually intended for prospective parties to be able to choose the "cost of performance measure" is discussed more fully infra text accompanying notes 151-61.

10. The consideration requirement is not immutable if written agreements "under seal" serve as a contractual substitute for consideration. See U.C.C. § 2-203 (1976) (making inoperative "the law with respect to sealed instruments").

This default rule/immutable rule dichotomy also pervades other areas of the law that have contractual components. In the law of divorce, for example, wealth accrued before marriage is allocated according to default rules that can be altered in pre-nuptial agreements, while income earned after marriage is immutably divided. Similarly, the repayment priorities set by state debtor-creditor law can, like default rules, be reordered through private contract. The laws of intestacy are also default rules: they fill any testamentary gap, but can be contracted around. As discussed below, infra text accompanying notes 83-91, one can distinguish between defaults that must be bilaterally contracted around and defaults that may be unilaterally overcome.

11. See I. MacNeil, Contracts: Exchange Transactions and Relations 346-47 (1978); Calabresi \& Melamed, supra note 1; Easterbrook \& Fischel, The Economic Structure of Corporate Law, 89 Colum. L. REv. (forthcoming 1989) (manuscript at 21-30; on file with authors).

12. Note that even when there are negative externalities, third parties may be able to protect themselves without immutable rules. One implication of the Coase theorem is that in a world with no transaction costs, third parties will have an incentive to contract to reduce externalities to an efficient level. See Coase, The Problem of Social Cost, 3 J. Law \& Econ. 1 (1960). There are no externalities if the class of parties to the potential contract is defined broadly enough. G. Priest, Internalizing Costs (Yale Law School Program in Civil Liability 1988; working paper no. 93) (explicating pervasiveness of private incentives to internalize costs). 
whether in particular contexts parentalistic concerns or externalities are sufficiently great to justify the use of immutable rules. ${ }^{13}$

When the preconditions for immutability are not present, the normative legal analysis devolves to the choice of a default rule. Yet academics have paid little attention about how to choose among possible default rules. ${ }^{14}$ The law-and-economics movement has fought long and hard to convince courts to restrict the use of immutable rules, ${ }^{15}$ but has lost most of its normative energy in constructing a theory of default choice. ${ }^{16}$ Economists seem to believe that, even if lawmakers choose the wrong default, at worst there will be increased transaction costs of a second order of magnitude. ${ }^{17}$

Few academics have gone beyond one-sentence theories stipulating that default terms should be set at what the parties would have wanted. ${ }^{18}$

13. A recent conference (Dec. 9-10, 1988) on "Contractual Freedom in Corporate Law" at Columbia's Center for Law and Economic Studies focused directly on the appropriate application of immutable rules. For example, Jeffrey Gordon argued that having multiple precedents that construe a single legal standard produces positive externalities that might justify imposing an immutable rule. See J. Gordon, The Mandatory Structure of Corporate Law (Dec. 2, 1988) (unpublished manuscript on file with authors).

14. Courts or legislatures are inevitably forced to set defaults, because contracts with gaps need to be interpreted. Courts must do something-even if that something is non-enforcement. As discussed infra text accompanying notes 51-52, defaults of non-enforcement can play an important role in efficient law.

15. For instance, Anthony Kronman has written:

$[\mathrm{E}] \mathrm{x}$ ante arguments for the efficiency of a particular legal rule assume that individuals remain

free to contract around that rule, and a legal system that denies private parties the right to

vary rules in this way will tend to be less efficient than a system that adopts the same rules but permits contractual variation.

Kronman, Specific Performance, 45 U. CHI. L. REv. 351, 370 (1978). See Haddock, Macey \& McChesney, Property Rights in Assets and Resistance to Tender Offers, 73 VA. L. Rev. 701, 736 (1987) ("The ability of firms to contract around costly legal rules when lower-cost private alternatives are available must be a feature of any efficient standard-form contract."); see also Goetz \& Scott, Liquidated Damages, Penalties and the Just Compensation Principle: Some Notes on an Enforcement Model and a Theory of Efficient Breach, 77 CoLuM. L. REv. 554 (1977) (arguing that "immutable" standards for determining enforceability of liquidated damages clauses should be relaxed). But see Clarkson, Miller \& Muris, Liquidated Damages v. Penalties: Sense or Nonsense?, 1978 WIs. L. Rev. 351 (providing efficiency rationale for immutable liquidated-damages rules).

16. For example, Haddock and Macey have suggested that immutable rules against insider trading are inefficient but have remained agnostic about whether corporations wishing to allow their insiders to trade should be forced to "opt out" of an insider trading prohibition, or whether corporations wishing to prohibit insider trading should be forced to "opt in" to such a system. Haddock \& Macey, A Coasian Model of Insider Trading, 80 Nw. U.L. Rev. 1449 (1987).

17. See, e.g., Easterbrook \& Fischel, Limited Liability and the Corporation, 52 U. CHI. L. REv. 89,102 (1985) ("In light of the ability of firms to duplicate or at least approximate either limited or unlimited liability by contract, does the legal rule of limited liability matter? The answer is yes, but probably not much.").

18. Looking backward to what the present litigants "would have wanted" is analytically analogous to looking forward to what prospective contractors will want. It is to ask (as Lea Brilmayer often does) "who are the prospective parties rooting for?" In both cases the court examines ex ante incentives. While ex post each party will have economic incentives to shift costs to the other side, ex ante the parties have an incentive to place the risks on the least-cost avoider. Kronman, Mistake, Disclosure, Information and the Law of Contracts, $7 \mathrm{~J}$. LEGAL STUd. 1 (1978). If a court can identify that ex ante the parties to the contract had identical interests in allocating a certain risk or duty of performance, then it can, in a sense, pierce the ex post adversarial veil. Thus, for example, even if ex post a particular tenant wants to avoid the risk of fire damage, ex ante both landlords and tenants may have preferred to have tenants bear this risk as the least-cost avoider. Thus, the fact that after a fire a tenant tries to avoid liability is not dispositive of what prospective tenants would contract for or, 
Frank Easterbrook and Daniel Fischel have championed the "would have wanted" theory in a number of articles suggesting that "corporate law should contain the [defaults] people would have negotiated, were the costs of negotiating at arms'-length for every contingency sufficiently low."19 Similarly, Richard Posner has argued that default rules should "economize on transaction costs by supplying standard contract terms that the parties would otherwise have to adopt by express agreement."20 Douglas Baird and Thomas Jackson have argued that the default rules governing the debtor-creditor relationship "should provide all the parties with the type of contract that they would have agreed to if they had had the time and money to bargain over all aspects of their deal." ${ }^{21}$ While this literature has vigorously examined what particular parties would have contracted for in particular contractual settings, ${ }^{22}$ it has failed to question whether the "would have wanted" standard is conceptually sound. ${ }^{23}$

Thus, although the academy recognizes the analytic difference between

indeed, of what this particular tenant would have contracted for.

19. Easterbrook \& Fischel, supra note 11 at 14-15; see also id. at 20-21 (default term should be "the term that the parties would have selected with full information and costless contracting"); Easterbrook \& Fischel, Corporate Control Transactions, 91 YALE L.J. 698, 702 (1982) (default fiduciary duties are derived from a hypothetical contract, imagined by judges, between investors and managers dickering with each other free of bargaining costs); Easterbrook \& Fischel, The Proper Role of a Target's Management in Responding to a Tender Offer, 94 HaRv. L. REv. 1161, 1182 (1981) (corporate law should supply "standard form 'contracts' of the sort shareholders would be likely to choose ....."). Calabresi and Melamed's analysis may be an early antecedent of the "would have wanted" analysis. They argue that efficiency-minded law would establish default entitlements as the parties would allocate them in a world without transaction costs. Calabresi \& Melamed, supra note 1, at 1093-98.

20. R. PoSNer, supra note 2, at 372; see also Schwartz, Proposals for Products Liability Reform: A Theoretical Synthesis, 97 YALE L.J. 353, 361 (1988) (offering as default rule "the contract that most well-informed persons would have adopted if they were to bargain about the matter").

21. Baird \& Jackson, Fraudulent Conveyance Law and Its Proper Domain, 38 VAND. L. Rev. 829, 835-36 (1985); see also Goetz \& Scott, The Mitigation Principle: Toward a General Theory of Contractual Obligation, 69 VA. L. REv. 967, 971 (1983) ("Ideally, the preformulated rules supplied by the state should mimic the agreements contracting parties would reach were they costlessly to bargain out each detail of the transaction.").

In Lewis v. Benedict Coal Corp., 361 U.S. 459 (1960), the Supreme Court applied this defaultsetting standard in deciding whether, in the absence of explicit contractual language, payments to a third-party beneficiary pension fund should be subject to setoff if the union breaches the underlying labor contract. The Court stated, "[i]t may be fair to assume that had the parties anticipated the possibility of a breach by the promisee they would have provided that the promisor might protect himself by such means as would be available against the promisee under a two-party contract." Id. at 468 (emphasis added). The Court later distinguished what parties to a collective bargaining agreement might have wanted and accordingly established a no-setoff default. Id. at 469 .

22. See, e.g., Craswell, Contract Remedies, Renegotiation, and the Theory of Efficient Breach, 61 S. CAL. L. REV. 629 (1988); see also infra text accompanying notes 136-39 (discussing judicial disagreement of Judges Easterbrook and Posner).

23. Charles Goetz and Robert Scott have written one of the more thoughtful examinations of default choice. Goetz \& Scott, The Limits of Expanded Choice: An Analysis of the Interactions Between Express and Implied Contract Terms, 73 CALIF. L. REv. 261 (1985). Their theory of default rules is based on the idea that a large body of precedent will develop regarding the interpretation and application of a standard-form clause. Parties who contract around a standard-form clause will face the prospect that courts will interpret their contract in a manner that is inconsistent with the parties' initial intentions. Thus, parties who prefer an alternative to the standard-form may accept the latter for fear of misinterpretation. 
default and immutable rules, a detailed theory of how defaults should be set has yet to be proposed. Indeed, the lack of agreement over even what to call the "default" concept is evidence of the underdeveloped state of default theory. ${ }^{24}$ Default rules have alternatively been termed background, backstop, enabling, fallback, gap-filling, off-the-rack, opt-in, opt-out, preformulated, preset, presumptive, standby, standard-form and suppletory rules. ${ }^{25}$

This Article provides a theory of how courts and legislatures should set default rules. We suggest that efficient defaults would take a variety of forms that at times would diverge from the "what the parties would have contracted for" principle. To this end, we introduce the concept of "penalty defaults." Penalty defaults are designed to give at least one party to the contract an incentive to contract around the default rule and therefore to choose affirmatively the contract provision they prefer. In contrast to the received wisdom, penalty defaults are purposefully set at what the parties would not want-in order to encourage the parties to reveal information to each other or to third parties (especially the courts).

This Article also distinguishes between tailored and untailored defaults. A "tailored default" attempts to provide a contract's parties with precisely "what they would have contracted for." An "untailored default," true to its etymology, provides the parties to all contracts with a single, off-therack standard that in some sense represents what the majority of contracting parties would want. The Restatement (Second) of Contracts' approach to filling gaps, for example, provides tailored defaults that are "reasonable in the circumstances." "Reasonable" defaults usually entail a tailored determination of what the individual contracting parties would have wanted because courts evaluate reasonableness in relation to the "cir-

24. The "default" characterization seems currently in vogue. Professor Robert Clark explains its ctymology:

For those who haven't been exposed to this jargon from the world of computers, "default rules" are the rules that a program follows in "default" of an explicit choice by the user to have some other principle apply. For example, your word processing program may set paper margins of 1 inch on all sides unless you take the trouble to learn the relevant commands and set the margins otherwise.

Clark, Contracts, Elites, and Traditions in the Making of Corporate Law, 89 Colum. L. REv. (forthcoming 1989) (manuscript at 3 n.9; on file with authors).

25. See Bebchuk, Limiting Contractual Freedom in Corporate Law: The Desirable Constraints on Charter Amendments, 102 HaRv. L. Rev. 1820 (1989) (using "opt-out" and "opt-in"); Coffee, The Mandatory/Enabling Balance in Corporate Law: An Essay on the Judicial Role, 89 ColUM. L. REV. (forthcoming 1989) (using "enabling"); Easterbrook \& Fischel, supra note 11 (using "standby," "enabling," "presets," and "fallback"); Eisenberg, The Foundational Model of the Corporation, 89 Colum. L. REv. (forthcoming 1989) (using "enabling" and "suppletory" terms); Goetz \& Scott, supra note 21, at 971 (using "preformulated"); Haddock, Macey \& McChesney, supra note 15, at 736 (using "default" and "standard-form"); Schwab, supra note 1, at 237 (using "presumptive" and "off-the-rack"); Speidel, Restatement Second: Omitted Terms and Contract Method, 67 CoRnelL L. REv. 785 n.2 (1982) (using "gap-filling").

26. Restatement (SECOND) OF Contracts $\$ 204$ ("Supplying an Omitted Essential Term") (setting default for missing term to be "a term which is reasonable in the circumstances"). See Speidel, supra note 25 , at $792-809$. 
cumstances" of the individual contracting parties. ${ }^{27}$ In contrast, Charles Goetz and Robert Scott have proposed that courts should set untailored default rules by asking "what arrangements would most bargainers prefer?"28

This Article provides a general theory of when efficiency-minded courts or legislatures should set penalty defaults and how they should choose between tailored and untailored default rules. Some common-law and statutory defaults are flatly at odds with the "would have wanted" principle. Although this Article does not make the full-blown positivist claim that current default rules are efficient, it does offer a more complete explanation of the current diversity of defaults.

An essential component of our theory of default rules is our explicit consideration of the sources of contractual incompleteness. We distinguish between two basic reasons for incompleteness. ${ }^{29}$ Scholars have primarily attributed incompleteness to the costs of contracting. Contracts may be incomplete because the transaction costs of explicitly contracting for a given contingency are greater than the benefits. ${ }^{30}$ These transaction costs may

27. For example, U.C.C. § 2-306, governing output and requirement contracts, establishes as a default that: In the absence of a stated estimate, "no quantity unreasonably disproportionate . . . to any normal or otherwise comparable prior output or requirements may be tendered or demanded." U.C.C. \$ 2-306(1) (1976). In determining reasonableness, courts are expressly asked by the U.C.C. to look at specific characteristics of the contracting parties. For example, "[a] shut-down by a requirements buyer for lack of orders might be permissible when a shut-down merely to curtail losses would not." U.C.C. $\$ 2-306(1)$ comment 2 (1976).

28. Goetz \& Scott, supra note 21 , at 971 (emphasis in original).

29. There are two distinct ways for a contract to be incomplete. First, a contract may fail to specify the parties' duties for specific future contingencies. For example, a contract for the construction of a third floor to a house may not state the parties' respective rights and responsibilities should the entire house burn down before construction is started. Since construction of a third floor is impossible (without the lower two floors), the contract does not cover the contingency of the house burning down.

The second form of contractual incompleteness is more subtle. A contract may also be incomplete in that it is insensitive to relevant future contingencies. Under this second form of contractual incompleteness, parties' duties are fully specified, but the contracts are incomplete because those specified duties are not tailored to economically relevant future events. See K. Spier, Incomplete Contracts in a Model with Adverse Selection and Exogenous Costs of Enforcement (Dec. 1988) (unpublished manuscript on file with authors) (discussing causes for such incompleteness). For example, consider a contract that simply obligates one party to construct a garage adjacent to a house. On the face this contract imposes a duty to build a garage whether or not the adjacent house burns down before construction of the garage is complete. The contract is incomplete in this second sense, however, because the duty to build a garage is not sufficiently dependent on future contingencies. If the adjacent house burns down, the parties probably would want to adjust the terms of contract. Such contracts we call insufficiently state-contingent.

Courts recognize the first form of incompleteness and know they must decide how to fill the gap. For instance, non-enforcement is one way courts can fill the gap. Courts seldornly recognize the second form of contractual incompleteness. That is, they are generally unwilling to alter (they strictly enforce) the terms of a contract that is insufficiently state-contingent. The main exception to strict enforcement is the doctrine of impossibility (or economic impracticability) with which couris sometimes refuse enforcement when performance, although literally possible, is not ex post efficient. See Posner \& Rosenfield, Impossibility and Related Doctrines in Contract Law: An Economic Analysis, 6 J. Legal Stud. 83, 87 (1977) (discussing legal contours of impossibility doctrine).

30. See O. Williamson, The Economic Institutions of Capitalism 70 (1985); MacNeil, Contracts: Adjustment of Long-Term Economic Relations Under Classical, Neoclassical and Relational Contract Law, 72 Nw. U.L. Rev. 854, 871-73 (1978); Shavell, Damage Measures for Breach 
include legal fees, negotiation costs, drafting and printing costs, the costs of researching the effects and probability of a contingency, and the costs to the parties and the courts of verifying whether a contingency occurred. Rational parties will weigh these costs against the benefits of contractually addressing a particular contingency. If either the magnitude or the probability of a contingency is sufficiently low, a contract may be insensitive to that contingency even if transaction costs are quite low.

The "would have wanted" approach to gap filling is a natural outgrowth of the transaction cost explanation of contractual incompleteness. Lawmakers can minimize the costs of contracting by choosing the default that most parties would have wanted. If there are transaction costs of explicitly contracting on a contingency, the parties may prefer to leave the contract incomplete. Indeed, as transaction costs increase, so does the parties' willingness to accept a default that is not exactly what they would have contracted for. Scholars who attribute contractual incompleteness to transaction costs are naturally drawn toward choosing defaults that the majority of contracting parties "would have wanted" because these majoritarian defaults seem to minimize the costs of contracting.

We show, however, that this majoritarian "would have wanted" approach to default selection is, for several reasons, incomplete. First, the majoritarian approach fails to account for the possibly disparate costs of contracting and of failing to contract around different defaults. ${ }^{31}$ For example, if the majority is more likely to contract around the minority's preferred default rule (than the minority is to contract around the majority's rule), then choosing the minority's default may lead to a larger set of efficient contracts. Second, the received wisdom provides little guidance about how tailored or particularized the "would have wanted" analysis should be. ${ }^{32}$ Finally, the very costs of ex ante bargaining may encourage parties to inefficiently shift the process of gap filling to ex post court determination. ${ }^{33}$ If it is costly for the courts to determine what the parties would have wanted, it may be efficient to choose a default rule that induces the parties to contract explicitly. In other words, penalty defaults are appropriate when it is cheaper for the parties to negotiate a term ex ante than for the courts to estimate ex post what the parties would have wanted. Courts, which are publicly subsidized, should give parties incentives to negotiate ex ante by penalizing them for inefficient gaps.

of Contract, 11 BELL. J. EcoN. 466, 468 (1980) (" [B]ecause of the costs involved in enumerating and bargaining over contractual obligations under the full range of relevant contingencies, it is normally impractical to make contracts which approach completeness.").

31. See infra Section II.

32. Id.

33. Jeffrey Gordon argues that the "would have wanted" approach is also flawed because it shifts risks to the ex ante least-cost avoider but, as applied by most courts, does not in fact compensate the ex post risk bearer. Gordon, supra note 13, at 61 (problem with hypothetical bargain argument, "like other Kaldor-Hicks arguments, is that it doesn't guarantee that each party will in fact receive a bigger slice, or a slice of the right size." (citation omitted)). 
This Article also proposes a second source of contractual incompleteness that is the focus of much of our analysis. We refer to this source of incompleteness as strategic. ${ }^{34}$ One party might strategically withhold information that would increase the total gains from contracting (the "size of the pie") in order to increase her private share of the gains from contracting (her "share of the pie"). By attempting to contract around a certain default, one party might reveal information to the other party that affects how the contractual pie is split. Thus, for example, the more informed party may prefer to have inefficient precaution rather than pay a higher price for the good. ${ }^{35}$ While analysts have previously explained incomplete contracting solely in terms of the costs of writing additional provisions, we argue that contractual gaps can also result from strategic behavior by relatively informed parties. By changing the default rules of the game, lawmakers can importantly reduce the opportunities for this rent-seeking, strategic behavior. ${ }^{36}$ In particular, the possibility of strategic incompleteness leads us to suggest that efficiency-minded lawmakers should sometimes choose penalty defaults that induce knowledgeable parties to reveal information by contracting around the default penalty. The strategic behavior of the parties in forming the contract can justify strategic contractual interpretations by courts. ${ }^{37}$

Our analysis therefore moves beyond the received wisdom that default rules should simply be what the majority of contracting parties would have wanted. In choosing among default rules, lawmakers should be sensitive to the costs of contracting around, and the costs of failing to contract around, particular defaults. We show that different defaults may lead to different degrees of "separating" and "pooling." ${ }^{38}$ In "separating" equilibria, the different types of contracting parties, by bearing the costs of contracting around unwanted defaults, separate themselves into distinct

34. See infra Section II for examples of strategic incompleteness. A third reason for contractual incompleteness is that some contingencies may simply be unforeseen by all contracting parties. In this case, the default rule will not affect the actions of the parties since by definition they do not consider the contingency in deciding what to do. There will normally be no reason to consider the rule's ex ante effect because it will have none.

There is one caveat to this statement: Behavior may be affected if parties are aware that unforeseen contingencies exist but are unable to ascertain the nature of these contingencies. For example, parties who are aware that a variety of unforeseen contingencies may affect the price at which they should transact may choose a contract that includes a reasonable price clause rather than fixing a price or a price rule as a function of foreseen contingencies. In this way the price can respond to unforeseen contingencies. See D. Kreps, Static Choice in the Presence of Unforeseen Contingencies (Aug. 1988) (unpublished manuscript on file with authors) for a utility-theoretic characterization of behavior in the presence of unforeseen contingencies. The choice of optimal defaults for such unforeseen contingencies is beyond the scope of this article. For a discussion of the appropriate default, see Posner \& Rosenfield, supra note 29.

35. See K. Spier, supra note 29 (formalizing this strategic reluctance to reveal information).

36. See infra Section I-C.

37. Inefficient strategic behavior will often induce efficiency-promoting counterstrategies by other economic actors. See Easterbrook, Predatory Strategies and Counterstrategies, 48 U. CHI. L. REv. 263 (1981).

38. See infra text accompanying notes 113-16. 
contractual relationships. In "pooling" equilibria, different types of contracting parties fail to contract around defaults, thus avoiding transaction costs but bearing the inefficiencies of the substantive default provisions.

In contrast to the majoritarian analysis, our analysis shows that it may be efficient to choose a rule that a majority of people actually disfavor. To set defaults efficiently, lawmakers must not only know what contracting parties want, but how many are likely to get it and at what cost. We recommend a greater and more explicit legal sensitivity toward the ways in which different defaults will affect the resulting contractual "equilibrium."39

Finally, before deciding how to fill gaps, courts must decide whether the contract even has a gap. In other words, courts must decide whether the contract already allocates a particular risk or duty. We show that this issue of whether a gap exists is identical to the issue of what is sufficient to contract around a particular default. ${ }^{40}$ While the received wisdom is that lawmakers should minimize the costs of contracting around default rules, ${ }^{41}$ we suggest that efficiency-minded courts and legislatures may want to intentionally increase these transaction costs to discourage parties from contracting around certain defaults.

The Article has three sections. Section I discusses the possible efficiency of penalty defaults. Section II embeds penalty defaults in a more general model of default choice, a model which suggests when penalty, tailored, or untailored defaults will be efficient. Section III then develops a theory of gap definition that determines what should be sufficient to contract around a given default.

\section{Penalty Default Rules}

\section{A. The Zero-Quantity Default}

The diversity of default standards can even be seen in contrasting the law's treatment of the two most basic contractual terms: price and quantity. Although price and quantity are probably the two most essential issues on which to reach agreement, the U.C.C. establishes radically different defaults. If the parties leave out the price, the U.C.C. fills the gap with "a reasonable price." ${ }^{\prime 2}$ If the parties leave out the quantity, the

39. We will sometimes find it useful to distinguish between situations in which the parties negotiate in ignorance of the default rule and situations in which the parties negotiate in the shadow of the default rule. In the former case, the parties do not know how the courts will decide if the contingency in question occurs, while in the latter case the parties know the legal default (but may not know certain information about the other party). See infra text accompanying notes 58-60.

40. See infra Section III.

41. See Easterbrook \& Fischel, supra note 11, at 21-30.

42. U.C.C. $\$ 2-305(1)$ reads: "The parties if they so intend can conclude a contract for sale even though the price is not settled. In such a case the price is a reasonable price at the time for delivery. . . " U.C.C. \$ 2-305(1) (1976). 
U.G.G. refuses to enforce the contract. ${ }^{43}$ In essence, the U.G.C. mandates that the default quantity should be zero.

How can this be? The U.C.C.'s reasonable-price standard can be partly reconciled with the received wisdom that defaults should be set at what the parties would have contracted for. ${ }^{44}$ But why doesn't the U.C.G. treat a missing quantity term analogously by filling the gap with the reasonable quantity that the parties would have have wanted? Obviously, the parties would not have gone to the expense of contracting with the intention that nothing be exchanged.

We suggest that the zero-quantity default cannot be explained by a "what the parties would have wanted" principle. Instead, a rationale for the rule can be found by comparing the cost of ex ante contracting to the cost of ex post litigation. The zero-quantity rule can be justified because it is cheaper for the parties to establish the quantity term beforehand than for the courts to determine after the fact what the parties would have wanted.

It is not systematically easier for parties to figure out the quantity than the price ex ante, but it is systematically harder for the courts to figure out the quantity than the price ex post. To estimate a reasonable price, courts can largely rely on market information of the type "How much were rutabagas selling for on July 3 ?"45 But to estimate a reasonable quantity, courts would need to undertake a more costly analysis of the individual litigants of the type "How much did the buyer and seller value the marginal rutabagas?"

43. U.C.C. \$2-201 states that a "contract ... is not enforceable under this [provision] beyond the quantity of goods shown. . . "U.C.C. \$ 2-201(1) (1976). The official comment adds that "[t]he only term which must appear is the quantity term which need not be accurately stated but recovery is limited to the amount stated." U.C.C. \$ 2-201(1) (official comment) (1978). In some cases, lack of a quantity term will merely be evidence that the parties did not have a meeting of the minds. But even if there are sufficient objective indicia of an intent to contract (and even if the statute of frauds is not raised as an affirmative defense), courts may refuse to enforce the contract because it is indefinite. See Jessen Bros. v. Ashland Recreation Ass'n., 204 Neb. 19, 281 N.W.2d 210 (1979) (contract for sod unenforceable for lack of specific quantity term); Burke v. Campbell, 258 Mass. 153, 154 N.E. 759 (1927) (contract unenforceable in part because contract did not state how much stock defendant would receive in exchange for financing corporation); King v. Krischer Mfg. Co., 220 A.D. 584, 222 N.Y.S. 66 (1927) (contract unenforceable because "a quantity of merchandise" too indefinite).

44. A simple "what parties would have wanted" approach has trouble explaining why the parties would choose reasonable price at time of delivery instead of at the time of contracting. There is no reason to think that parties would systematically prefer one risk allocation to the other. However, one can determine the efficient default rule by asking the question, "why didn't the parties explicitly contract for price?" Those parties who wish to allocate the risk of cost fluctuations to the seller will most likely contract for a price at the time of contracting. Those who wish to allocate the risk to the buyer will attempt to contract for a time-of-delivery, cost-based price. Such a clause may be costly to write into the contract explicitly because of the difficulty in measuring the seller's cost exactly. The parties may instead prefer to rely on reaching an agreement in the shadow of the court's reasonableprice default rule.

45. This analysis suggests that courts would be less likely to enforce contracts in "thin" markets in which the market price is not readily ascertainable. See Haddock, McChesney \& Spiegel, An Ordinary Economic Rationale for Extraordinary Legal Sanctions, 78 CALIF. L. REv. (forthcoming 1990) (discussing how efficient legal rules will turn on "thickness" of market). 
The U.C.C.'s zero-quantity default is what we term a "penalty default." Because ex ante neither party would want a zero-quantity contract, such a rule penalizes the parties should they fail to affirmatively specify their desired quantity. Because the non-enforcement default potentially penalizes both parties, it encourages both of them to include a quantity term. ${ }^{48}$

\section{B. Toward a More General Theory of Penalty Defaults}

Penalty defaults, by definition, give at least one party to the contract an incentive to contract around the default. From an efficiency perspective, penalty default rules can be justified as a way to encourage the production of information. ${ }^{47}$ The very process of "contracting around" can reveal information to parties inside or outside the contract. Penalty defaults may be justified as 1) giving both contracting parties incentives to reveal information to third parties, especially courts, ${ }^{48}$ or 2 ) giving a more informed contracting party incentives to reveal information to a less informed party.

The zero-quantity default, for instance, gives both contracting parties incentives to reveal their contractual intentions when it would be costly for a court to discover that information ex post. This justification-that ex ante contracting can be cheaper than ex post litigation-can also explain the common law's broader rule that "for a contract to be binding the terms of the contract must be reasonably certain and definite." 49 Similarly, this rationale can explain corporate statutes that give incorporators an incentive to affirmatively declare the number of authorized shares, the address of the corporation for legal process and, indeed, the state of incor-

46. Even if the judicial system were not subsidized, the zero-quantity default might be justified on parentalistic concerns. For example, if private parties are uninformed or systematically underestimate the costs of ex post judicial determination of a "reasonable" quantity, it might be in society's interests to dissuade parties from mistakenly failing to negotiate the contract quantity ex ante.

This rationale for this penalty default depends on the assumption that the private parties pay less than the full costs of their ex post litigation. The parties may lower their transaction costs by shifting the privately funded ex ante negotiations to publicly subsidized ex post litigation. If parties fully internalized ex post litigation costs, at first cut they should be able to choose the cheaper type of negotiation.

47. In encouraging the revelation of information, lawmakers should be sensitive to the influence that defaults can have on the incentives for private parties to acquire information in the first place. See infra notes 93-94 and accompanying text.

48. Penalty defaults may be established to provide information to third parties other than the courts. For example, in corporate law certain alterations to the default corporate governance can be accomplished through a by-law amendment, while other alterations can only be made by changing the articles of incorporation. See infra note 148 and accompanying text. Requiring certain amendments in the articles of incorporation reveals information to interested third parties, such as creditors, because these articles are publicly filed with the Secretary of State. See, e.g., Revised Model Business CoRP. ACT ANN. $\$ 2.01$ (1987) (requiring filing of articles of incorporation).

49. Steinberg v. Chicago Medical School, 41 Ill. App. 3d 804, 807, 354 N.E.2d 586, 589 (1976); see also Parks v. Atlanta News Agency, 115 Ga. App. 842, 156 S.E.2d 137 (1967); 1 A. CorbIN, Corbin on Contracts $\S 95$ (1952 \& Supp. 1989); 1 S. Williston, A Treatise on the Law of CONTRACTS $\$ 37$ (3d ed. $1957 \&$ Supp. 1978). 
poration. ${ }^{50}$ Statutes that refuse to enforce corporate charters without these provisions create incentives similar to those created by the common law's refusal to enforce vague or indefinite contracts. In both cases, the parties can make these contractual choices more efficiently ex ante.

Lawmakers should select the rule that deters inefficient gaps at the least social cost. When the rationale is to provide information to the courts, the non-enforcement default is likely to be efficient. Non-enforcement defaults are likely to provide least-cost deterrence because they are inexpensive to enforce and give each party incentives to contract around the rule. It might seem that a penalty default set solely against one side of a contract would be sufficient to get both sides to reveal information. For example, a penalty default that makes the seller sell at one-tenth the market price would certainly encourage sellers to affirmatively fill any price gaps. But one side's penalty may be the other side's windfall. One-sided penalties can create incentives for opportunism. ${ }^{51}$ The non-penalized buyer in the above example would have incentives to induce sellers to enter indefinite contracts in order to extract the penalty rent. ${ }^{52}$ By taking each party back to her ex ante welfare, the non-enforcement default eliminates this potential for opportunism.

In contrast, when the rationale is to inform the relatively uninformed contracting party, the penalty default should be against the relatively informed party. ${ }^{53}$ This is especially true when the uninformed party is also uninformed about the default rule itself. If the uninformed party does not know that there is a penalty default, she will have no opportunistic incentives.

In some situations it is reasonable to expect one party to the contract to be systematically informed about the default rule and the probability of the relevant contingency arising. If one side is repeatedly in the relevant contractual setting while the other side rarely is, it is a sensible presumption that the former is better informed than the latter. Consider, for example, the treatment of real estate brokerage commissions when a buyer breaches a purchase contract. Such contracts typically include a clause which obligates the purchaser to forfeit some given amount of "earnest" money if she breaches the agreement. How should the earnest money be

50. See Revised Model Business Corp. Act AnN. $\$ 2.02$ (1987).

51. Posner defines opportunism (in relation to the common-law contractual duty to act in good faith) as "taking advantage of the vulnerability of the other party to a contract . . . that is due to the sequential character of performance." R. POSNER, supra note 2 , at 81 .

52. Similar opportunistic incentives have been analyzed in other areas of contract law. See, e.g., Clarkson, Miller \& Muris, Liquidated Damages Versus Penalties: Sense or Nonsense?, 1978 Wis. L. REv. 351 (non-enforcement of penalty clauses prevents opportunistic breach inducement); Goetz \& Scott, supra note 15, at 586 (mitigation requirement eliminates incentive for opportunism by abligee in case of breach). More generally, the inefficiency of excessive penalties has been detailed in the economics-of-crime literature. See, e.g., R. Posner, supra note 2, at 205-12; Becker, Crime and Punishment: An Economic Approach, 76 J. PoL. Econ. 169 (1968).

53. See infra text accompanying notes 57-73. 
split between the seller and the broker if their agency contract does not address this contingency? Some courts have adopted a "what the parties would have wanted" approach and have awarded all the earnest money to the seller. ${ }^{54}$ We agree with this outcome, but for different reasons. ${ }^{55}$ The real estate broker will more likely be informed about the default rule than the seller. Indeed, the seller may not even consider the issue of how to split the earnest money in case of default. ${ }^{56}$ Therefore, if the efficient contract would allocate some of the earnest money to the seller, the default rule should be set against the broker to induce her to raise the issue. Otherwise, if the default rule is set to favor the broker, a seller may not raise the issue, and the broker will be happy to take advantage of the seller's ignorance. By setting the default rule in favor of the uninformed party, the courts induce the informed party to reveal information, and, consequently, the efficient contract results.

Although social welfare may be enhanced by forcing parties to reveal information to a subsidized judicial system, it is more problematic to understand why society would have an efficiency interest in inducing a relatively informed party to a transaction to reveal information to the relatively uninformed party. After all, if revealing information is efficient because it increases the value created by the contract, one might initially expect that the informed party will have a sufficient private incentive to reveal information-the incentive of splitting a bigger pie. This argument ignores the possibility, however, that revealing information might simultaneously increase the total size of the pie and decrease the share of the pie that the relatively informed party receives. If the "share-of-the-pie effect" dominates the "size-of-the-pie effect," informed parties might rationally choose to withhold relevant information. ${ }^{57}$

Parties may behave strategically not only because they have superior

54. See, e.g., Dennis Reed, Ltd. v. Goody, 2 K.B. 277 (1950); see also J. Dukeminier \& J. Krifr, Property 554-55 (2d ed. 1988) (discussing evolution of common-law rule).

55. Earnest money is used to force the purchaser to internalize the cost to the seller of taking the property off the market during the time from the signing of the sale agreement to the closing or, in this case, the breach. Since these costs are largely incurred by the seller, she should receive the compensation. Furthermore, the seller may wish to give the broker incentives to find a buyer who will not default. Allowing the broker to share in the earnest money will lower or eliminate this incentive. One reason, however, that the broker and the seller would ex ante contract for the broker to receive some of the earnest money is that the breach by the initial buyer may necessitate a quick sale which may cause the seller to lower the selling price. This, in turn, would lower the broker's commission. Thus, a "what the parties would have wanted" approach might yield a default in which a risk-averse broker receives a portion of the earnest money.

56. Of course, people hire lawyers in part to ascertain the relevant negotiation issues, contingencies, and default rules. Our argument is therefore most applicable in contractual settings in which lawyers are not employed.

57. Withholding socially valuable private information to obtain private gains is common. Companies may withhold information about innovations from competitors to increase profits; car buyers may withhold information about particular options or accessories that they value if this information signals to car dealers a greater willingness to pay for the underlying automobile; and professional athletes may withold information about injuries to increase their salaries, even though as a result their team may inefficiently hire reserves. 
information about the default, but also because they have superior information about other aspects of the contract. We suggest that a party who knows that a particular default rule is inefficient may choose not to negotiate to change it. The knowledgeable party may not wish to reveal her information in negotiations if the information would give a bargaining advantage to the other side.

How can it be that by increasing the total gains from contracting (the size-of-the-pie effect) the informed party can end up with a smaller share of the gains (the share-of-the-pie effect) ${ }^{58}$ This Article demonstrates how relatively informed parties can sometimes benefit by strategically withholding information that, if revealed, would increase the size of the pie. A knowledgeable buyer, for example, may prefer to remain indistinguishable from what the seller wrongly perceives to be the class of similarly situated buyers. By blending in with the larger class of contractors, a buyer or a seller may receive a cross-subsidized price because the other side will bargain as if she is dealing with the average member of the class. A knowledgeable party may prefer to remain in this inefficient, but crosssubsidized, contractual pool rather than move to an efficient, but unsubsidized, pool. If contracting around the default sufficiently reduces this cross-subsidization, the share-of-the-pie effect can exceed the size-of-thepie effect because the informed party's share of the default pie was in a sense being artificially cross-subsidized by other members of the contractual class. Under this scenario, withholding information appears as a kind of rent-seeking ${ }^{89}$ in which the informed party foregoes the additional value attending the revealed information to get a larger piece of the contractual pie. ${ }^{60}$

58. If, under a given set of default rules, a seller wants to sell a sweater that she values at $\$ 50$ to a buyer who values it at $\$ 150$, then without contracting around any of the defaults the parties' agreement will create $\$ 100$ of value. The total gain from contracting, in other words, will be $\$ 100$. The parties will split this gain in value between themselves by bargaining for a price between $\$ 50$ and $\$ 150$. Suppose, however, that the buyer (and only the buyer) has information that would make the sweater worth $\$ 200$ to him if the seller would take on a duty that is outside of the default provisions and that would cost the seller $\$ 10$. The total gains from this non-default exchange would be $\$ 140$ $(\$ 200-\$ 50-\$ 10)$. How could the buyer lose by revealing information that increased the size of the pie by $\$ 40$ ? If the parties accept the default provisions and negotiate a $\$ 100$ price (implying that each party receives a $\$ 50$ share of the total gains), how can it be that revealing the value-enhancing information-by contracting for the non-default duty-would reduce the buyer's share to less than $\$ 50$ (implying that the negotiated price would exceed $\$ 150$ and that the seller's share would exceed \$90)?

59. Most broadly, rent-seeking "arises wherever parties have an incentive to expend real resources to capture something of value." V. GoldBERG, Readings in THE Economics of Contract LAw 49 (1989). Strategic withholding represents a species of rent-seeking because the relatively informed party commits the real resources of an inefficient contract to capture the cross-subsidization.

60. An equity-minded court might encourage information revelation to foster an equitable distribution of the gains from contracting, even if doing so reduces those gains. 


\section{Penalty Defaults in Action}

\section{Uncompensated Damages in Hadley v. Baxendale}

An example of how a penalty default can restrict rent-seeking behavior can be seen in the venerable case, Hadley $v$. Baxendale. ${ }^{61}$ In Hadley a miller in Gloucester contracted with a carrier to have a broken crank shaft transported to Greenwich. The shipment was delayed, and the miller sued the carrier for consequential damages of the profits lost while the mill was inoperative. The court, holding that only foreseeable consequential damages should be awarded, reversed a damage award and remanded for a new trial. $^{62}$

The holding in Hadley operates as a penalty default. The miller could have informed the carrier of the potential consequential damages and contracted for full damage insurance. ${ }^{63}$ The Hadley default of denying unforeseeable damages may not be consistent with what fully informed parties would have wanted. The miller's consequential damages were real and the carrier may have been the more efficient bearer of this risk. As a general matter, millers may want carriers to compensate them for consequential damages that carriers can prevent at lower cost. $^{64}$ The default can instead be understood as a purposeful inducement to the miller as the more informed party to reveal that information to the carrier. Informing the carrier creates value because if the carrier foresees the loss, he will be able to prevent it more efficiently. ${ }^{65}$ At the same time, however, revealing

61. 9 Ex. 341, 156 Eng. Rep. 145 (1854). William Bishop has also discussed how the Hadley rule could promote efficient revelation of information. See Bishop, The Contract-Tort Boundary and the Economics of Insurance, 12 J. LEGAL STun. 241, 254 (1983); L. Bebchuk \& S. Shavell, Information and the Scope of Liability for Unusual Damages from Breach of Contract, (March 1983) (unpublished manuscript on file with authors).

62. Hadley, 9 Ex. at 356, 156 Eng. Rep. at 151-52.

63. There is some evidence that the miller in fact attempted to inform the carrier of the probable damages. Thus, it may be difficult for parties to contract around the Hadley default. For a discussion of how courts can alter the mutability of a default rule by varying the requirements for contracting around it, see infra Section III.

64. The efficient risk-sharing agreement between symmetrically-informed shippers (e.g., the miller in this case) and carriers will depend upon their relative attitudes toward risk, the ability of the carrier to prevent the damages, and the ability of the shipper to mitigate damages in case of breach.

Richard Posner and Richard Epstein argue that in many situations there are actions the shipper could take to reduce consequential damages. See R. PoSNER, supra note 2, at 114-15; Epstein, Beyond Foreseability: Consequential Damages in the Law of Contract, 18 J. LEGAL STUD. 105, 121-25 (1989). In such situations the parties would choose to share consequential damages through appropriate liquidated damage clauses. See Cooter, Unity in Tort, Contract, and Property: The Model of Precaution, 73 Calif. L. Rev. 1, 15 (1985). In Evra Corp. v. Swiss Bank Corp., 673 F.2d 951, 955-59 (7th Cir. 1982), Judge Posner attempts to determine what insurance arrangement the parties would have contracted for. Epstein prefers a less tailored rule that does not require the courts to analyze the relative abilities of both sides to reduce damages.

We proceed under the assumptions that the miller had no economically practical means of reducing the losses from delay (e.g., keeping a spare crankshaft in inventory would have been too expensive) and that both parties were risk-neutral. Under these assumptions the efficient contract is for the carrier who is the least-cost avoider to bear the costs of delay.

65. This is one lesson from Goetz and Scott's analysis of the anxious alumnus: A bus company driving Dean Smith to the Final Four would probably take more efficient precautions if it were 
the information to the carrier will undoubtedly increase the price of shipping. Nonetheless, so long as transaction costs are not prohibitive, a miller with high consequential damages will gain from revealing this information and contracting for greater insurance from the carrier because the carrier is the least-cost avoider.

This is not to say that there could not be an equally efficient market response if Hadley had gone the other way. If the default required carriers to compensate for unforeseeable consequential damages, low-damage millers would have the incentive to raise the issue of consequential damages. In a competitive industry, the uninformed carrier, in effect, assumes she is facing an average-damage miller and charges a price accordingly. The market price will reflect the expected cost of insuring high-damage millers. A low-damage miller will want to contract for less-than-average insurance and, therefore, a lower price. But the gains from contracting around the default may be insignificant if the proportion of millers with high damages is small. Furthermore, it may be very difficult for a lowdamage miller to determine how much of the price is an implicit insurance premium for millers with higher damages.

Thus, there may be situations in which the low-damage millers fail to contract for the low-insurance/low-price contract. In the resulting equilibrium, carriers may charge a price representing their average cost of serving both high- and low-damage millers and take an average amount of precaution (which will be relatively low if there are relatively few highdamage millers).$^{66}$ Richard Posner suggests a similar result: If the damage default changed so that manufacturers of photographic film were liable for unforeseen consequential damages, "[t]he manufacturer of the film will probably take no additional precautions . . . because he cannot identify the films whose loss would be extremely costly, and unless there are many of [the high-damage photographers] it may not pay to take additional precautions on all the films he develops." ${ }^{\text {"67 }}$ Section II formalizes this discussion of Hadley to show that low-damage millers might fail to contract around a default that awarded unforeseeable damages while high-damage millers will contract around the Hadley rule. ${ }^{68}$

warned of how large Dean Smith's consequential damages would be were he to miss the game. Goetz \& Scott, supra note 15 , at 578 .

66. The uninformed parties, the carriers, could simply exclude unforeseeable consequential damages from their standard-form contract (thereby contracting around the default at very low cost), and high-damage millers, if they want insurance, could simply contract around the contract default. In other words, if the legal default rule is inefficient, contracting parties may have ways of supplanting it with a default of their own. (This point can also be made with regard to Posner's story about film development; see infra text accompanying note 67.) The limits to this contractual response to the contra-Hadley default are discussed infra notes 70-71 and text accompanying notes 69-71.

67. R. POSNER, supra note 2, at 114 (emphasis in original).

68. In the economics literature several articles examine situations in which asymmetric information induces inefficient contracting. See, e.g., Akerlof, The Market for "Lemons": Quality Uncertainty and the Market Mechanism, 84 Q.J. ECON. 488 (1970); Myerson, Mechanism Design by an Informed Principal, 51 ECONOMETRICA 1767 (1983). 
It is important to consider another channel for informatio. :elation. The uninformed party, the carrier, may attempt to learn the expected damages of the informed parties, the millers, by offering a menu of insurance contracts. ${ }^{69}$ The millers might then be induced to self-select the insurance contract that is optimal for their expected damages. ${ }^{70}$ The problem faced by uninformed parties trying to induce information revelation, however, is that in many situations the necessary menu is more complicated than in the common carrier example. Devising a menu that induces information revelation may require a great deal of sophistication by the uninformed party and may entail large transaction costs. ${ }^{71}$

The main lesson to draw from our discussion of Hadley is that there may be strategic reasons for parties' choosing not to reveal information. If the default rule awarded all consequential damages, to be sure, the lowdamage millers would want to distinguish themselves from the highdamage millers. But the high-damage millers may intentionally choose to withhold information that would make their contracts more efficient. An informed party may not realize the full social value of revealing the information and, hence, her private benefits from revealing may diverge from the social benefits of having the information revealed. As elaborated below, by not distinguishing themselves, informed parties may be able to free-ride on the lower-cost qualities of others and thereby contract at a subsidized price. To counteract this strategic behavior, courts should choose defaults that are different from what the parties would have wanted.

Easterbrook and Fischel have argued that courts should choose defaults that "the parties would have selected with full information and costless contracting." 22 Their standard fittingly tracks the two reasons for contractual incompleteness that we have identified-strategic withholding and transaction costs. In a sense, their standard seeks what the parties would have selected if there were no barriers to contractual completeness. ${ }^{73} \mathrm{We}$ disagree, however, with their conclusion that courts should choose the default that the parties would have selected with "full information." When

69. See supra note 66.

70. This is in fact done by many common carriers. The Federal Express standard contract, for example, limits consequential damages to $\$ 100$ but permits the shipper to buy greater insurance at stated rates. See Epstein, supra note 64, at 120.

71. See, e.g., infra text accompanying note 81 (consumers trying to ascertain information about dealer's expected lost-profit damages may encounter significant resistance in devising menu that encourages dealers to reveal information). For an example of a menu that would require large transaction costs and sophistication on the part of the uninformed party, see Note, Imperfect Information, The Pricing Mechanism, and Products Liability, 88 Colum. L. Rev. 1057 (1988) (suggesting that manufacturers should be required to provide menus of warranties so that consumers can judge quality and safety of products).

72. Easterbronk \& Fischel, supra note 11 , at 20-21.

73. Full information by both parties would eliminate any opportunity for strategically withholding information, and costless contracting obviously eliminates transactions costs as an impediment to complete contracting. 
relatively informed parties strategically withhold information, courts, to promote information revelation, should choose a default that the informed party does not want. Imposing ex post what completely informed parties would have contracted for may not result in the ex ante revelation necessary for efficient reliance or precaution. For example, we have shown that in Hadley fully informed parties may have wanted the carrier to be fully liable for consequential damages. Yet choosing full liability as the damage default may lead carriers to invest suboptimally in accident prevention. Hadley is inconsistent with a full-information, "what the parties would have wanted" standard. Instead, Hadley penalizes high-damage millers for withholding information that would allow carriers to take efficient precautions.

\section{Goldberg's Solution to the Lost-Profits Puzzle}

Victor Goldberg's analysis of the lost-volume retail seller ${ }^{24}$ comports with our discussion of penalty defaults. Goldberg examines what a retailer's damages should be when a customer breaches a contract to buy. The U.C.G. mandates, and other commentators have suggested, that the retailer should receive the lost profits on the good. ${ }^{75}$ Goldberg's own analysis suggests that the lost profits approximate the real loss borne by the retailer. But Goldberg instead proposes that courts deny "recovery for lost profits in the absence of explicit contract language to the contrary." other words, Goldberg proposes that the default damages be zero.

His rationale parallels our rationale for penalty defaults. The zerodamage default is intended to give retailers an incentive to come forward and contract for a nonrefundable deposit or for a liquidated damages clause. Again, the process of contracting around the default apprises the customer of her potential liability. A sales contract gives the consumer an option either to purchase the product or to pay damages. Goldberg's zerodamage default encourages retailers to inform consumers about the price of exercising the option to breach. Consumers will therefore internalize the cost to the retailer of breach and more efficiently take precautions against breach. ${ }^{77}$ Furthermore, the consumer may not know the default rule for breach. ${ }^{78}$ If a consumer is unaware that the default rule makes

74. Goldberg, An Economic Analysis of the Lost-Volume Retail Seller, 57 S. CAL. L. REv. 283 (1984).

75. See U.C.G. \& 2-708(2) (1976); Goetz \& Scott, Measuring Sellers' Damages: The Lost-Profits Puzzle, 31 Stan. L. Rev. 323, 323 (1979); Speidel \& Clay, Seller's Recovery of Overhead Under UCC Section 2-708(2): Economic Cost Theory and Coniract Remedial Policy, 57 CoRnel. L. Rev. 681, 694 (1972).

76. Goldberg, supra note 74 , at 291 .

77. In this situation the uninformed party, the consumer, probably could not offer a menu of contracts to the informed retailer to induce revelation of the markup. See supra text accompanying notes 69-71. The information requirements, complexity, and transaction costs of such a scheme would be prohibitive.

78. This is similar to our earlier discussion of what the real estate default rule should be for 
her liable for lost profits, the seller will have little incentive to bargain about damages. ${ }^{79}$ Consumer liability for lost profits can lead to efficient breach and precaution only if consumers know the amount of their liability. The zero-damages penalty default encourages the retailer to reveal her markup. ${ }^{80}$

Although consumers would value this markup information, retailers still have incentives to withhold it. ${ }^{81} \mathrm{By}$ revealing their profits, retailers may simultaneously reduce their bargaining power. Even Goldberg's penalty default, therefore, could be too weak to induce information disclosure. Retailers may sometimes prefer to take their chances with zero damages for breach rather than disclose a high markup. If the zero-damage penalty default is insufficient to induce information revelation, a stiffer penalty may be necessary to induce the parties to contract for liquidated damages. ${ }^{82}$

\section{Unilateral Defaults as Penalties: The Perverse Incentives of Lefkowitz}

Some contractual rules establish defaults that individual parties may unilaterally change. Consider, for example, the legal effect of offers. The U.C.C.'s mandate that an offer intends any reasonable form of acceptance is a unilateral default that obtains "unless otherwise unambiguously indicated." ${ }^{83}$ Consistent with the preceeding analysis, lawmakers may want to set penalty defaults that encourage offerors to reveal information to offerees. Thus, courts may want to choose the default that the offeror does not want.

In Lefkowitz v. Great Minneapolis Surplus Store, Inc., ${ }^{84}$ the Minnesota Supreme Court rejected the plaintiff's claim that the defendant, a retailer, had failed to honor two advertised offers that the plaintiff had accepted. $^{85}$ In the first offer the defendant had advertised the sale of three

splitting earnest money between the seller and the broker when a buyer breaches a purchase contract. See supra text accompanying notes 54-56.

79. If the seller raises the issue of damages, thereby revealing her markup, consumers can more efficiently take precautions to avoid breach. Since the consumer will learn she is liable for damages, however, she will insist on a lower price for the good.

80. Similarly, the common-law doctrine of construing ambiguities in contracts against the drafter, see I. MACNEIL, supra note 11 , at 372 , can be viewed as a penalty default. The doctrine is not based on the judgment that the parties would have wanted the anti-drafter provision, but that such a penalty encourages drafters to draft more precise contracts.

81. For a fuller discussion of this point, see Ayres \& Miller, "I'll Sell It To You At Cast": Legal Methods to Promote Honest Retail Markup Disclosure, 84 Nw. U.L. REv. (forthcoming 1990) (manuscript on file with authors).

82. It is not necessarily true, however, that retailers will reveal their markups via their choice of liquidated damages. All retailers may uniformly negotiate for minimal liquidated damages that provide no more information than the zero-damage default.

83. U.C.C. $\$ 2-206(1)(1976)$.

84. 251 Minn. 188, 86 N.W.2d 689 (1957).

85. The court concluded that the newspaper advertisements constituted offers and not merely invitations to make an offer. Id. at 192, 86 N.W.2d at 691. 
fur coats " "Worth to $\$ 100.00$ " " for " $\$ 1$ Each" "; in the second offer the defendant advertised the sale of one black lapin stole " "worth $\$ 139.50$ " " for " $\$ 1.00$ " " contracts are not enforceable, refused to enforce the contract arising out of the first offer but awarded the plaintiff damages for his attempted acceptance of the second.

The court reasoned that the first offer's estimate that the coat was " 'worth to $\$ 100$ " " was too speculative and uncertain to award damages. ${ }^{87}$ But in applying the common-law standard that indefinite contracts are unenforceable, the court ignored the likely market response to the nonenforceability default. As argued above, non-enforceability can be viewed as a penalty default that encourages both parties to come forward and fill in the gap; ${ }^{88}$ that is, refusing to enforce indefinite contracts drives out indefinite contracts. In Lefkowitz, however, the court's refusal to enforce the indefinite offer leads to exactly the opposite result.

Ask yourself the simple question: What kind of ad is the Great Minneapolis Surplus Store going to run the week following the court's decision? By lending its imprimatur to the indefinite ad, the court allows retailers to induce inefficient consumer reliance with impunity. ${ }^{80}$ The Lefkowitz case dramatically illustrates that only by enforcing indefinite offers against the offeror can one drive out indefinite offers.

Lefkowitz was wrongly decided. The defendant's offer was intentionally vague to induce inefficient reliance on the part of the buyer (Lefkowitz incurred the "shoe-leather" costs of traveling to the store). Courts can retain the common law's general reluctance to enforce indefinite contracts so that both parties will have an incentive to make the contracts more definite. ${ }^{90}$ But Lefkowitz illustrates an exception to this general rule. When the indefiniteness is clearly attributable to one party and induces inefficient reliance from the other party, punitive enforcement may be efficient to drive out inefficient indefinite offers.

\section{Summary}

Penalty defaults stand as stark counter-examples to the proposition that courts should simply choose defaults that the parties would have wanted. ${ }^{91}$ Particularly when individual parties have private incentives to withhold

86. Id, at 189,86 N.W.2d at 690 .

87. Id. at 190,86 N.W.2d at 690 .

88. See supra text accompanying notes 49-52.

89. Our argument that consumers will be "suckered" into the store by non-enforceable, indefinite offers assumes that consumers are unable to distinguish between enforceable and unenforceable offers.

90. See supra text accompanying note 88 .

91. It could be argued that rational contractual parties behind a "veil of ignorance" would want penalty defaults that increase the total gains to contracting. Cf. J. RAwLS, A THEORY of JUSTICE 24-38 (1974) (discussing preferences under utilitarian assumptions of persons behind "veil of ignorance"). 
information, it may be desirable for the law to give them a nudge. The possibility that efficient defaults will at times be used to reflect what most people want while at other times be used to encourage the revelation of information is analogous to the disparate uses of presumptions in the laws of evidence. ${ }^{92}$ In both instances, the law is sometimes chosen to promote the revelation of information.

Finally, having shown that lawmakers will sometimes want to set defaults that encourage one or both parties to reveal information, we now should warn lawmakers that they should sometimes protect the private incentives to become informed. In some instances forcing parties to reveal information will undermine their incentives to obtain the information in the first place. ${ }^{93}$ Lawmakers therefore should not impose penalty defaults that have a net effect of reducing the amount of socially useful information. But in some instances, a particular party may need to acquire certain types of information before contracting, so that forcing disclosure would have minimal disincentive effects. For instance, in Goldberg's example of lost-profit damages, retailers naturally knew the profits from a sale. It is hard, therefore, to conceive how forcing retailers to disclose their profits would undermine their private incentives to calculate the profitability of a sale. $^{94}$

92. The list of penalty defaults analyzed above is far from exhaustive. For example, the U.C.C. sections which cstablish implied or default warranties, U.C.C. $\$ \S 2-314$ and $2-315$, cannot easily be justified as "what the parties would have contracted for." Instead, the defaults, consistent with the foregoing analysis, force sellers to reveal information to consumers about the extent of their coverage. Indeed, one way to identify penalty defaults is to investigate the pervasiveness with which parties contract around them, as is done with the seemingly ubiquitous use of limited warranty disclaimers.

U.C.C. \$ 2-207 is also inconsistent with "would have wanted" default analysis. This section supplants the common-law mirror-image rule with the default that additional terms in an acceptance that do not materially alter the terms of the offer become part of a contract between merchants. This default cannot be reconciled with a "what the parties would have contracted for" analysis, because there is no reason to think that the merchants would have wanted to include the additional terms of their contract. Instead, the rule places an informational burden on the party with the last clear chance to come forward and notify the other side if the additional terms are objectionable.

Evidentiary presumptions in litigation are sometimes used to reflect a relationship between facts and at other times to place the burden of producing evidence on the party who is more likely to be informed. See Allen, Presumptions in Civil Actions Reconsidered, 66 IowA L. REv. 843, 845 (1981) (suggesting that presumptions are used "to construct rules of decision to avoid factual impasse at trial; to allocate burdens of persuasion; to instruct the jury on the relationship between facts; and to allocate burdens of production").

93. See R. PosNer, supra note 2, at 115; Easterbrook, Insider Trading, Secret Agents, Evidentiary Privileges, and the Production of Information, 1981 SuP. CT. REv. 309, 359; R. Allen, M. Grady, D. Polsby \& M. Yashko, Confidentiality of Legal Affairs (1988) (unpublished manuscript on file with authors); $t f$. Laidlaw v. Organ, 15 U.S. (2 Wheat.) 178 (1817) (permitting relatively informed contracting party to profit by keeping information to himself). Of course, much of patent law is justified as a means of encouraging the private production of information.

94. Anthony Kronman distinguishes "deliberately acquired information" from "casually acquired information." For example, he suggests that if one side to a contract is aware that the other has entered a mistaken bid, the special knowledge of the non-mistaken party "is unlikely to be the fruit of a deliberate search." Requiring disclosure by the knowledgeable party of this casually acquired information will accordingly not undermine incentives to become informed. Kronman, Mistake, Disclosure, Information, and the Law of Contracts, 7 J. LEGAL. STUD. 1, 32 (1978) (revealing lost profits from contract can undermine incentives for parties to search for undervalued assets). There may be a tradeoff between inducing efficient search by one party and efficient breach by the other. Retailers do not 


\section{A General Theory of Default Choice}

The prior analysis of Hadley can be embedded in a more general model of default choice. To formalize our ideas, we begin by introducing some notation. Let the percentage of millers who had high (unforeseeable) damages be $\alpha_{\mathrm{H}}$ and the percentage of millers who had low (foreseeable) damages be $\alpha_{\mathrm{L}}{ }^{95}$ Let $\mathrm{D}_{\mathrm{H}}$ and $\mathrm{D}_{\mathrm{L}}$ be the monetary value of damages for the high- and low-damage millers, respectively. The court chooses between two possible defaults: denying or awarding the high, unforeseeable damages. Let the costs of contracting around these defaults be $c_{H}$ and $c_{L}$, where:

$\mathrm{c}_{\mathrm{H}}=$ cost of contracting around the Hadley default rule that denies awards for unforeseeable consequential damages; and

$\mathrm{c}_{\mathrm{L}}=$ cost of contracting around the default rule that awards unforeseeable consequential damages.

We assume that all parties are risk neutral, so the only goal of the insurance aspect of the contract is to induce the carrier to take efficient precaution. As argued above, in a world with full information, both highand low-damage millers would contract for the carrier to pay for their consequential damages. ${ }^{98}$ If the carrier knows the miller's type and bears all damages, she will choose the optimal level of precaution. ${ }^{97}$ Let $\mathrm{K}_{\mathrm{H}}$ and $\mathrm{K}_{\mathrm{L}}$ equal the carrier's optimal investment in precaution for the two types of millers, respectively. Let $\mathrm{q}_{H}$ and $\mathrm{q}_{\mathrm{L}}$ equal the probability of damages for each type of miller given the optimal level of precaution for the class. ${ }^{88}$

Before analyzing the likely equilibrium associated with each default, we must say a bit more about the carrier's price. Assume for the moment that the carrier is in a competitive market in which, by definition, there are zero economic profits. ${ }^{99}$ Let the competitive price of shipping crankshafts for known high-damage millers be $\mathrm{P}_{\mathrm{H}}$ and for known low-damage millers be $P_{L}$. With this notation, if $M C$ is the marginal cost of shipping with no precaution, then the following equations will hold:

$$
\begin{gathered}
\mathrm{P}_{\mathrm{H}}=M C+\mathrm{K}_{\mathrm{H}}+\mathrm{q}_{\mathrm{H}} \mathrm{D}_{\mathrm{H}}, \\
\mathrm{P}_{\mathrm{L}}=\mathrm{MC}+\mathrm{K}_{\mathrm{L}}+\mathrm{q}_{\mathrm{L}} \mathrm{D}_{\mathrm{L}} .
\end{gathered}
$$

search for their markup information-in Kronman's terminology it is not "deliberately acquired"-so that information revelation will enhance efficiency.

95. We assume that these are the only types of millers so that $\alpha_{\mathrm{H}}+\alpha_{\mathrm{L}}=1$. For a similar mathematical model of Hadley, see L. Bebchuk \& S. Shavell, supra note 61.

96. See supra text accompanying notes $62-70$.

97. We assume that the contract cannot mandate a specific level of precaution because neither the miller nor a court can observe the level of precaution. Otherwise, carriers might sort millers by offering different levels of precaution.

98. Thus, $K_{H}$ is the level of $K$ that minimizes the expression $K+q(K) D_{H}$, and $K_{L}$ is the level of $K$ that minimizes the expression $K+q(K) D_{L}$, where the function $q(K)$ equals the probability of damages from delay for a given level of precaution, $\mathrm{K}$.

99. Economic profits are the residual earnings after all implicit and opportunity costs are accounted for. 
Because of competition, these prices reflect the carrier's marginal cost of shipping, precaution, and expected damages.

What will the market equilibrium look like under the alternative defaults? First consider the Hadley low-damage default. Since the carrier is liable only for foreseeable damages, $D_{L}$, she will choose a precaution investment of $\mathrm{K}_{\mathrm{L}}$. The probability of damages will therefore be $\mathrm{q}_{\mathrm{L}}$, and the price will be $\mathrm{P}_{\mathrm{L}}$. Now we can ask whether the high-damage millers will contract around the low-damage default for higher insurance. If the highdamage millers fail to contract around the low-damage default, they will pay $P_{L}$ and, in addition, bear the probability of damage, $q_{L}$, multiplied by the uninsured damages $\left(D_{H}-D_{L}\right)$. Thus, the total expected cost, $P_{H}$ in, to the high-damage millers if they inefficiently fail to contract around the low-damage default is:

$$
P_{H}^{\text {in }}=P_{L}+q_{L}\left(D_{H}-D_{L}\right) \text {. }
$$

But because the carrier invests suboptimally in precaution, the millers' total expected cost in equation (3) must be greater than if the carrier had taken the efficient level of precaution and passed the cost on in the price, $\mathrm{P}_{\mathrm{H}}$ :

$$
\mathrm{P}_{\mathrm{H}}{ }^{\text {in }}>\mathrm{P}_{\mathrm{H} \cdot{ }^{100}}
$$

This difference $\left(P_{H}\right.$ in $\left.-P_{H}\right)$ represents the inefficiency $\left(f_{H}\right)$ associated with failing to contract for the efficient level of precaution:

$$
\mathrm{P}_{\mathrm{H}} \text { in }-\mathrm{P}_{\mathrm{H}}=\mathrm{f}_{\mathrm{H}} \text {. }
$$

" $\mathrm{f}_{\mathrm{H}}$ " then, represents the inefficiency cost when high-damage millers fail to contract for greater precaution. ${ }^{101}$ High-damage millers effectively pay:

$$
\mathrm{P}_{\mathrm{H}}{ }^{\text {in }}=\mathrm{P}_{\mathrm{H}}+\mathrm{f}_{\mathrm{H}}
$$

when they fail to contract around the Hadley low-damage default.

If the high-damage millers contract around this default, they should expect to bear the costs of the increased precaution as reflected in a higher shipping price $\left(\mathrm{P}_{\mathrm{H}}\right.$ rather than $\left.\mathrm{P}_{\mathrm{L}}\right)$ as well as the additional transaction costs of contracting around the default $\left(\mathrm{c}_{\mathrm{H}}\right){ }^{102}$ This total cost would be:

100. From equations (1), (2) and (3):

So that:

$$
\begin{gathered}
P_{H}{ }^{\text {in }} \stackrel{P_{L}}{=} \mathrm{q}_{L}\left(D_{H}-D_{L}\right)=M C+K_{L}+q_{L} D_{H}, \text { and } \\
P_{H}=M C+K_{H}+q_{H} D_{H}
\end{gathered}
$$

$$
P_{H} \text { in }-P_{H}=K_{L}+q_{L}\left(K_{L}\right) D_{H}-\left(K_{H}+q_{H}\left(K_{H}\right) D_{H}\right) \text {. }
$$

Because $\mathrm{K}_{\mathrm{H}}$ minimizes $\mathrm{K}+\mathrm{q}(\mathrm{K}) \mathrm{D}_{\mathrm{H}}$, see supra note $98, \mathrm{~K}_{\mathrm{L}}+\mathrm{q}_{\mathrm{L}}\left(\mathrm{K}_{\mathrm{L}}\right) \mathrm{D}_{\mathrm{H}}$ must be larger than $\mathrm{K}_{\mathrm{H}}+\mathrm{q}_{\mathrm{H}}\left(\mathrm{K}_{\mathrm{H}}\right) \mathrm{D}_{\mathrm{H}}$. Therefore, the right side of this equation must be positive, and inequality (4) must hald.

101. From the previous note we can calculate the inefficiency cost:

$$
\mathrm{f}_{\mathrm{H}}=\mathrm{K}_{\mathrm{L}}+\mathrm{q}_{\mathrm{L}} \mathrm{D}_{\mathrm{H}}-\left(\mathrm{K}_{\mathrm{H}}+\mathrm{q}_{\mathrm{H}} \mathrm{D}_{\mathrm{H}}\right)=\left(\mathrm{q}_{\mathrm{L}}-\mathrm{q}_{\mathrm{H}}\right) \mathrm{D}_{\mathrm{H}}-\left(\mathrm{K}_{\mathrm{H}}-\mathrm{K}_{\mathrm{L}}\right) \text {. }
$$

This latter expression illustrates that the inefficiency of low precaution derives from the fact that the costs of the higher probability of damage, $\left(\mathrm{q}_{\mathrm{L}}-\mathrm{q}_{\mathrm{H}}\right) \mathrm{D}_{\mathrm{H}}$, outweigh the lower costs of precaution, $\left(\mathrm{K}_{\mathrm{H}}\right.$ $\mathrm{K}_{\mathrm{L}}$ ).

102. The high-damage millers bear all of these additional transaction and precaution costs because competition will keep the carrier's price at marginal cost. 
(7)

$\mathrm{P}_{\mathrm{H}}+\mathrm{c}_{\mathrm{H}}$.

Thus, the high-damage millers will contract around the low-damage default if the total cost of failing to contract $\left(\mathrm{P}_{\mathrm{H}}+\mathrm{f}_{\mathrm{H}}\right)$ exceeds the total costs of contracting $\left(\mathrm{P}_{\mathrm{H}}+\mathrm{c}_{\mathrm{H}}\right)$ : or more simply if:

$$
\mathrm{P}_{\mathrm{H}}+\mathrm{f}_{\mathrm{H}}>\mathrm{P}_{\mathrm{H}}+\mathrm{c}_{\mathrm{H}} \text {, }
$$

$-\mathrm{f}_{\mathrm{H}}>\mathrm{c}_{\mathrm{H}}$.

High-damage millers will contract around the Hadley, low-damage default when the cost of inefficient precaution $\left(f_{H}\right)$ is larger than the cost of contracting around the default $\left(c_{\mathrm{H}}\right)$. If the additional costs of contracting around the Hadley default are sufficiently small, all high-damage millers will contract for the efficient amount of insurance. The high-damage millers will effectively pay $\mathrm{P}_{\mathrm{H}}+\mathrm{c}_{\mathrm{H}}$ for shipping, while the low-damage millers will pay $P_{L}$.

Now consider the non-Hadley, high-damage default. ${ }^{103}$ If the percentage of high-risk millers, $\alpha_{H}$, is sufficiently small, market competition may produce an equilibrium in which no one contracts around the default and the carriers take only low levels of precaution, $\mathrm{K}_{\mathrm{L}}{ }^{104}$ If the carriers cannot distinguish between high- and low-damage millers, competition would cause the shipping price to become:

(10) $\mathrm{P}^{*}=\alpha_{\mathrm{L}} \mathrm{P}_{\mathrm{L}}+\alpha_{\mathrm{H}} \mathrm{P}_{\mathrm{H}}$.

Since in a competitive market, carriers must charge a price equal to the expected average cost of serving both high- and low-damage millers, $\mathrm{P}^{*}$ represents a weighted average of these costs. The low-damage millers cost the carriers $P_{L}$, while the high-damage millers cost the carriers $P_{H}{ }^{\text {in }}$ if the inefficient, low level of precaution is taken. ${ }^{105}$

This will be the equilibrium if neither the high- nor the low-damage millers have an incentive to reveal to the carrier their specific type. We might think that the low-damage millers would have an incentive to come forward and reveal their status in order to receive a lower contract price. But they will do so only if:

$$
\mathrm{c}_{\mathrm{L}}<\mathrm{P}^{*}-\mathrm{P}_{\mathrm{L}}{ }^{106}
$$

Contracting around the high-damage default will be profitable only if the savings from the reduced shipping price $\left(\mathrm{P}^{*}-\mathrm{P}_{\mathrm{L}}\right)$ are greater than the

103. We assume that the costs to the court of determining the magnitude of unforeseeable cansequential damages-i.e., determining whether a given miller is type $\mathrm{H}$ or type $\mathrm{L}$-are negligible.

104. If precaution investment is a continuous choice variable (for example, the length of time spent training carriers how to drive safely), its optimal level will be between $\mathrm{K}_{\mathrm{L}}$ and $\mathrm{K}_{\mathrm{H}}$. For small $\alpha_{H}$ the investment will be close to $K_{L}$. If there are discrete choices for the level of precaution (for example, use two or three horses) and $\alpha_{\mathrm{H}}$ is small enough, the optimal investment will be $\mathrm{K}_{\mathrm{L}}$.

105. Substituting equations (2) and (3) into equation (10) yields:

$$
P^{*}=M C+K_{L}+q_{L} D_{L}+\alpha_{H} q_{L}\left(D_{H}-D_{L}\right)
$$

which, again substituting equation (2), simplifies to:

$$
\mathrm{P}^{*}=\mathrm{P}_{\mathrm{L}}+\alpha_{\mathrm{H}} \mathrm{q}_{\mathrm{L}}\left(\mathrm{D}_{\mathrm{H}}-\mathrm{D}_{\mathrm{L}}\right) \text {. }
$$

106. From the prior footnote, this inequality can be expressed as:

$$
c_{L}<\alpha_{H} q_{L}\left(D_{H}-D_{L}\right)
$$


additional transaction cost, $c_{L}$. But from equation (10) we see that the equilibrium price, $\mathrm{P}^{*}$, is a positive function of $\alpha_{\mathrm{H}}$, the percentage of highdamage millers. ${ }^{107}$ If this percentage $\left(\alpha_{\mathrm{H}}\right)$ is sufficiently low, the transaction costs $\left(c_{L}\right)$ will keep the low-damage millers from contracting around the high-damage default. Note that this is unlike the low-damage default in which the incentives to contract around the default rule are based on the gains to the high-damage millers and are independent of the percentage of the population that has high damages $\left(\alpha_{\mathrm{H}}\right)$.

The high-damage millers will not reveal their true status to the carriers because they would be forced to pay more $\left(\mathrm{P}_{\mathrm{H}}-\mathrm{P}^{*}\right)$ but would gain no additional coverage. The high-damage millers fail to distinguish themselves not because of transaction costs, but because they prefer to withhold this information strategically and to receive the subsidized shipping price. ${ }^{108}$ The shipping price is subsidized because transaction costs prevent low-damage millers from contracting around the default. Even though the information is socially valuable because it leads to more efficient precaution and even though this value exceeds the transaction costs, the highdamage millers prefer to remain undistinguished from their low-risk counterparts. The high-damage millers do not mind that carriers take inefficiently low levels of precaution because, like all shippers, high-damage millers are fully insured. The low-damage millers bear the costs of this inefficiency, but are not hurt enough individually to distinguish themselves contractually.

Prior analyses of incomplete contracts have suggested that parties fail to contract around inefficient defaults because of transaction costs. ${ }^{102}$ Our analysis is striking because it demonstrates the possibility that parties may fail to contract around defaults for strategic reasons. ${ }^{110} \mathrm{~A}$ relatively informed party may strategically withhold information that would increase the joint gains from trade. ${ }^{111}$ Moreover, the example illustrates two extreme forms of default equilibria. The Hadley, low-damage default caused all high-damage millers to contract around the rule and thus engendered

107. One could imagine situations in which the costs for low-damage millers of contracting around a high-damage default would be small. For example, the Federal Express standard-form contract limits consequential damages if the sender does not contract for more insurance. See supra note 70. Such a standard form would allow low-damage millers to cheaply opt for low-damage protection and consequently a lower price.

108. In other words, even if the costs of contracting for higher precaution were zero, the highdamage millers would not reveal their status.

109. See supra note 30 .

110. In our simplified model, low-damage millers failed to contract around the pooling equilibrium because of transaction costs. See supra inequality (11). In a more general model, however, even without transactions costs the informed cross-subsidizing parties (such as the low-damage millers) may fail to contract around pooling equilibria if in doing so they reveal information which reduces their bargaining power. See K. Spier, supra note 29 for a more formal demonstration of why similar strategic concerns can keep contracts from being efficiently state-contingent.

111. This, then, is an example in which the "share-of-the-pie effect" exceeds the "size-of-the-pie" effect. See supra text accompanying note 57. 
what economists sometimes call a "separating" equilibrium in which different types of contracting parties sort themselves through the competitive process into different groups at different prices. In contrast, the nonHadley, high-damage default created a "pooling" equilibrium in which the high- and low-damage millers failed to distinguish themselves to the carriers. ${ }^{112}$

The tension between "pooling" and "separating" equilibria is crucial in choosing the efficient default. Separating equilibria entail the additional transaction costs of causing some parties to contract around the rule; pooling equilibria entail the costs of inefficient reliance or precaution for failing to contract around the rule. ${ }^{113}$ In the Hadley example the transaction cost of the high-damage millers' contracting around the low-damage default is $\alpha_{\mathrm{H}} \mathrm{c}_{\mathrm{H}}$. This is the cost of separating equilibria. The cost of the high-damage default stems from the inefficiently low precaution that carriers take with regard to the high-damage millers, $\alpha_{\mathrm{H}} \mathrm{f}_{\mathrm{H}}$. This is the cost of pooling equilibria. If inequality (9) holds (i.e., if $f_{H}>c_{H}$ ), then the costs of pooling exceed the costs of separating, and the Hadley default is efficient even though it is not what the high-damage millers would have wanted.

Although the prior section described the Hadley rule as a penalty default, it can be alternatively conceived as an untailored default rule that provides what the majority of the parties would want (since under our assumptions, $\alpha_{\mathrm{L}}>\alpha_{\mathrm{H}}$ ). This reconception suggests that untailored defaults that apply a single rule to different types of contracting parties act as penalty defaults with regard to those parties who disfavor them. Because a majority of the millers had low damages $\left(\alpha_{\mathrm{L}}>\alpha_{\mathrm{H}}\right)$ and would only want to contract for low damages, one might deduce that the untailored Hadley rule is efficient because a majority of the parties prefers it.

But the commonly accepted notion that untailored defaults should be set at what the majority of parties wants does not hold in a more general model of default choice in which the pooling and separating equilibria are not extreme. To extend the Hadley model, consider the choice between

112. This analysis is consonant with the economics of insurance literature. See, e.g., Rothschild \& Stiglitz, Equilibrium in Competitive Insurance Markets: An Essay on the Economies of Imperfect Information, 90 Q.J. EcoN. 629, 634-37 (1976) (discussing "separating" and "pooling" equilibria). Low-risk insureds will have incentives to drop out of (or separate from) pools in which they crosssubsidize the premiums of high-risk insureds. See generally Priest, The Current Insurance Crisis and Modern Tort Law, 96 YALE L.J. 1521 (1987) (arguing that this sort of separation has occurred in third-party insurance pools and is largely responsible for recent "insurance crisis").

113. In this model all millers continue to ship crankshafts regardless of the default rule. If, however, the cross-subsidization of the non-Hadley default reduced the consumption of the low-damage millers (who must pay $\mathrm{P}^{*}-\mathrm{P}_{\mathrm{L}}$ more) or increased the consumption of the high-damage millers (who have to pay $\mathrm{P}_{\mathrm{H}}-\mathrm{P}^{*}$ less), then the pooling equilibria would additionally entail the dead-weight losses associated with inefficient amounts of contracting. See Note, Contract Damages and CrossSubsidization, 61 S. GAL. L. REV. 1125 (1988). 
two defaults: one and two. As above, there will be a certain percentage of the population of contracting parties for which each default would be preferred, $\alpha_{1}$ and $\alpha_{2}$, respectively. ${ }^{114}$ Again, there will be costs of contracting around each default, $c_{1}$ and $c_{2}$ : let $c_{1}$ be the cost of contracting around default two to the default one rule (and define $c_{2}$ analogously). The Hadley model showed that failing to contract around a default could result in inefficient levels of precaution. ${ }^{115}$ Accordingly, let $f_{1}$ equal the inefficiency generated if a type one contracting party fails to contract for the type one rule (and analogously define $\mathrm{f}_{2}$ ). Most important, in a more general model there may be intermediate amounts of pooling and separation for the different defaults. Accordingly, let:

$\beta_{1}=$ the percentage of type one contracting parties who in equilibrium would actually contract around default two, and

$\beta_{2}=$ the percentage of type two contracting parties who in equilibrium would actually contract around default one.

Thus, while $\alpha_{1}$ percent of the contracting parties prefer default one, it is possible that if default two is the rule, a smaller percent $\left(\beta_{1}<\alpha_{1}\right)$ would contract around it for the efficient amount of precaution. And analogously, some type two contracting parties might not contract around default one if it is the rule $\left(\beta_{2}<\alpha_{2}\right)$. $^{\text {116 }}$

The completeness of the Hadley pooling equilibrium implies that $\beta_{\mathrm{H}}=$ $\alpha_{\mathrm{H}}$, while the completeness of the non-Hadley separating equilibrium implies that $\beta_{\mathrm{L}}=0$. These extreme results turn on the homogeneity of, for example, $\mathrm{f}_{\mathrm{H}}$ and $\mathrm{c}_{\mathrm{H}}$. More generally, if high-damage millers have heterogeneous costs of contracting or of failing to contract, then different defaults may engender intermediate forms of pooling and separating.

In this more general model, each default can engender both costs of contracting and costs of failing to contract. For example, the costs of default one will be:

$$
c_{2} \beta_{2}+f_{2}\left(\alpha_{2}-\beta_{2}\right)
$$

which equal the transaction costs of those type two contractors who contract around default one $\left(c_{2} \beta_{2}\right)$ and the inefficient reliance or precaution costs for those type two parties who fail to contract around default one $\left(f_{2}\left(\alpha_{2}-\beta_{2}\right)\right)$. Default one will be optimal only if:

$$
c_{1} \beta_{1}+f_{1}\left(\alpha_{1}-\beta_{1}\right)>c_{2} \beta_{2}+f_{2}\left(\alpha_{2}-\beta_{2}\right) .
$$

This expression establishes the optimal condition for choosing between two untailored defaults. In equilibrium each default may cause a portion of the population to incur the expense of contracting around the default

114. $\alpha_{1}+\alpha_{2}=1$.

115. See supra text accompanying note 100 .

116. Because we assume that parties would never bargain for a less efficient contract, $\alpha_{1}$ and $\alpha_{2}$ will always be greater than or equal to $\beta_{1}$ and $\beta_{2}$ respectively. 
$\left(c_{i} \beta_{i}\right)$, and each rule may create costs $\left(f_{i}\left(\alpha_{i}-\beta_{i}\right)\right)$ for those parties that inefficiently fail to contract around it. The efficient default minimizes the sum of these two costs, which, as stated before, are themselves the costs of separation and pooling, respectively:

$$
\min _{\mathrm{i}=1,2}\left[\mathrm{c}_{\mathrm{i}} \beta_{\mathrm{i}}+\mathrm{f}_{\mathrm{i}}\left(\alpha_{\mathrm{i}}-\beta_{\mathrm{i}}\right)\right] .
$$

In contrast to the majoritarian analysis, condition (12) does not imply that efficiency-minded lawmakers should choose the default rule that most of the parties would want. In other words, condition (12) does not imply that:

$$
\alpha_{1}>\alpha_{2}
$$

Indeed, exploiting the fact that $\alpha_{2}=1-\alpha_{1}$, ${ }^{112}$ one can rearrange condition (12) in terms of $\alpha_{1}$. Default one will be efficient if and only if:

$$
\alpha_{1}>\frac{\mathrm{f}_{2}+\beta_{2}\left(c_{2}-\mathrm{f}_{2}\right)-\beta_{1}\left(c_{1}-\mathrm{f}_{1}\right)}{\mathrm{f}_{1}+\mathrm{f}_{2}}
$$

The right-hand side of this cumbersome inequality implicitly defines a critical value of $\alpha_{1}{ }^{*}$ for choosing between defaults one and two. When $\alpha_{1}$ is less than $\alpha_{1}{ }^{*}$, default two is efficient; when $\alpha_{1}$ is greater than $\alpha_{1}{ }^{*}$, default one is efficient.

The crude majoritarian criterion $\left(\alpha_{1}{ }^{*}=1 / 2\right)$ only emerges from highly constrained assumptions about $\beta_{1}, \beta_{2}, \mathrm{c}_{1}, \mathrm{c}_{2}, \mathrm{f}_{1}$, and $\mathrm{f}_{2}$. For example, the majoritarian default analysis in the existing contracts literature seems to derive from two divergent sets of assumptions about these crucial variables. ${ }^{118}$ One set of majoritarians seems to assume that transaction costs are small enough that no one fails to contract around inefficient defaults $\left(\alpha_{1}=\beta_{1}\right.$ and $\left.\alpha_{2}=\beta_{2}\right)$ and that the costs of contracting around each default are the same $\left(c_{1}=c_{2}\right) .{ }^{119}$ Under these assumptions, the second set of terms in condition (12) drop out of the analysis $\left(\mathrm{f}_{\mathrm{i}}\left(\alpha_{\mathrm{i}}-\beta_{\mathrm{i}}\right)=0\right)$, so that the costs of failing to contract are irrelevant. Inequality (13) can then be simplified to:

$$
\alpha_{1}>c_{2} /\left(c_{1}+c_{2}\right)=1 / 2
$$

which implies the majoritarian result that default one should be chosen only if a majority of the contracting parties prefers it.

A second set of majoritarians seems to assume that the transaction costs of contracting around a default are so great that no parties will contract around inefficient defaults $\left(\beta_{1}=\beta_{2}=0\right)$ and that the inefficiencies of failing to contract for the right rule are the same $\left(f_{1}=f_{2}\right)$. Under these assumptions the first terms of condition (12) drop out of the analysis $\left(c_{i} \beta_{i}\right.$ $=0$ ), so that inequality (13) can be simplified to:

$$
\alpha_{1}>f_{2} /\left(f_{1}+f_{2}\right)=1 / 2
$$

117. See supra note 114

118. See Craswell, supra note 22, at 632-39 (discussing two approaches).

119. Id. at 633 . 
which again implies that default one will be efficient only if a majority prefers it. Majoritarians are forced to make highly restrictive (and sometimes contradictory) assumptions to produce their desired rule. Most fundamentally, the majoritarian analysis errs by looking at only one of the relevant variables, $\alpha$.

As an alternative, some commentators have suggested that courts fill gaps with the provisions that most parties bargain for in actual contracts. ${ }^{120}$ Some academics have labelled this style of gap-filling as "mimicking-the-market."121 The "mimic-the-market" approach to default rules ignores the fact that the type of parties who contract around a given rule depends upon the rule itself. Parties who dislike a given default rule will contract around it; if we change the default rule to mimic the contracts these parties write, other types of parties may contract around the new default back to the original rule. This process could cycle forever. ${ }^{122}$ Set-

120. See Epstein, In Defense of the Contract at Will, 51 U. CHI. L. REv. 947, 951 (1984) (a default rule "is normally chosen because it reflects the dominant practice in a given class of cases and because that practice is itself regarded as making good sense for the standard transactions it governs."). Epstein argues that the default for consequential damages should be limited because this "is what the express contracts have typically provided." Epstein, supra note 64, at 118. Frank Easterbrook orally suggested a similar standard for choosing corporate default rules at the Columbia conference. See supra note 13.

The NLRB has looked at actual collective bargaining agreements in deciding whether there should be a default limiting management's right to transfer work. See Milwaukee II, 268 N.L.R.B. Dec. (CCH) 601, 603 (1984) (quoting Ozark Trailers, Inc., 161 N.L.R.B. Dec. (CCH) 561, 570 (1966) (citing M. Chander, Management Rights and Union Interests 217 (1964))). The Supreme Court has at times looked to actual contracting practices to determine whether a particular issue should be a mandatory subject of bargaining. See, e.g., First Nat'l Maintenance Corp. v. NLRB, 452 U.S. 666, 684 (1981); see also Alchian, Decision Sharing and Expropriable Specific Quasi-Rents: $A$ Theory of First National Maintenance Corporation v. NLRB, 1 SuP. CT. Econ. REv. 235 (1982) (suggesting how "decision sharing" default should be set); Wachter \& Cohen, The Law and Economics of Collective Bargaining: An Introduction and Application to the Problems of Subcontracting, Partial Closure, and Relocation, 136 U. PA. L. Rev. 1349, 1364-77 (1988) (suggesting how "default entitlements" in labor market should be set). However, in Lewis v. Benedict Coal Corp., 361 U.S. 459 (1960), discussed supra note 21, the Court eschewed any empirical analysis of the private reaction to a particular contract.

121. See Schwab, Collective Bargaining and the Coase Theorem, 72 CoRnell L. REv. 245, 286-87 (1987).

122. This is not to say that the mimic-the-market rule would never be desirable. If, for instance, filling a particular type of contractual gap is an issue of first impression, it may be reasonable for a court to look at existing contracts as a guide to what the parties would have wanted. If parties were unaware of the default rule when they were contracting, the cycling problem would not arise. If no well-established default exists, many contracting parties may explicitly contract for what they want in order to avoid the penalty of ex post uncertainty. In this case existing contracts provide evidence for what the parties would have done, so mimicking the market may be justified. For example, Epstein uses this approach to argue that one can ascertain the efficient form for workers' compensation legislation by observing the contractual insurance provisions that existed prior to legislation. Epstein, supra note 64 , at $118-19$.

Mimicking the market may also make sense when parties have failed to record any contract. For example, in devising their estates, many parties may not go to the trouble of writing a will, but those that do may restate even well-established intestacy defaults. Thus, looking at actual wills can give some guide to what the general populace wants. But even this argument fails if the contracting sample misrepresents the intestate class. If the reason certain parties fail to contract is related to the substantive provision that those parties want, then the inference between actual and hypothetical contracts is attenuated. For example, if only upper-class people can afford to write wills, then an upper-class preference for children over parents may not be relevant in determining the intestate preferences of 
ting defaults that mimic the market therefore will not assure efficiency. A slightly more sophisticated version of mimicking the market would set the default at what most people would contract around another default for. This approach would focus solely on the $\beta$ 's. For example, if a larger percentage of parties were willing to contract around the first default than the second default $\left(\beta_{2}>\beta_{1}\right)$, then rule two would be chosen as the default. But maximizing the $\beta$ 's suffers the same flaw as maximizing the $\alpha$ 's-neither choice rule conforms with the efficiency criterion in inequality (12). ${ }^{123}$

Implementing a complete theory of default choice requires attention to:

1) what the parties want (the $\alpha$ 's),

2) whether they will get it (the $\beta$ 's), and

3 ) the costs associated with getting it (the c's) or not getting it (the f's). It is especially important that lawmakers ascertain the degree of separating and pooling that each default engenders. For in determining the equilibrium levels of the $\beta$ associated with each default, the court must estimate the importance of transactional and strategic barriers to contracting around particular default rules, as well as understand the costs associated with failing to strike the efficient contract.

We have shown that at times the efficient default will be one that a majority of contracting parties disfavors. As the number of different types of preferred contracts (and consequently the number of possible defaults) increases, any untailored default is likely to be disfavored by the majority of contractors. ${ }^{124}$ Untailored defaults act as penalty defaults with regard to

the lower class.

123. Still another partial and inefficient criterion for default choice would attempt to minimize the number of people who failed to contract to their efficient rule. In the model's terminology, this would be equivalent to minimizing $\alpha_{i}-\beta_{i}$.

124. The results of this dichotomous model can be extended to a situation in which courts are choosing among more than two default alternatives. In many situations, there will be more than two possible default choices from which the lawmaker may choose. Consider a class of contracts in which tailoring is prohibitively expensive, so that the lawmaker must choose among $N(N>2)$ possible defaults. Assume that there are different classes of contracting parties for which different rules would be efficient. For example, heterogeneity across buyer risk preferences could lead to a range of optimal risk-sharing rules for different contracts. We assume that when parties contract around a default, they contract for the rule that is efficient for their class. But see Schwab, supra note 1, at 251 (students sometimes contracted around default to less efficient outcome). A contracting party will be called a type $j$ contracting party if default rule $j$ would be efficient for it. Let:

$\alpha_{i}=$ the percent of contracting parties who want default $i$ (where $\Sigma_{i} \alpha_{i}=1$ );

$\beta_{\mathrm{ij}}=$ the percent of type $\mathrm{j}$ contracting parties who will contract around default $\mathrm{i}$ (where $\beta_{\mathrm{ii}}=0$ );

$c_{i j}=$ the cost for type $j$ parties of contracting around default $i$; and

$f_{i j}=$ the cost for type $j$ parties of failing to contract around default $i$ (where $f_{i j}=0$ ).

Extending the earlier model, we can say that the cost of any default $i$ will be:

$$
\sum_{j=1, N}\left[c_{i j} \beta_{i j}+f_{i j}\left(\alpha_{j}-\beta_{i j}\right)\right] \text {. }
$$

which represents for all contracting types the total costs of contracting around default $i$ or of failing to contract around it. A lawmaker choosing the least-cost default will accordingly want to minimize:

$$
\min _{i=1, N}\left\{\sum_{j=1, N}\left[c_{i j} \beta_{i j}+f_{i j}\left(\alpha_{j}-\beta_{i j}\right)\right]\right\} \text {. }
$$

As in the dichotomous model, a penalty default may be the least costly. Even a default $x$ that no one wants, $\alpha_{x}=0$, may be optimal if most people contract around the default $\left(\beta_{x j} \sim \alpha_{x}\right.$, for all $\left.j\right)$, and 
the classes of contracting parties that disfavor them. As the diversity of contracting types grows, any untailored defaults start to resemble the types of penalty defaults we described in Section $I .{ }^{125}$ As the number of possible defaults expands, courts must choose between a penalty default that is efficient within the class of untailored defaults or a tailored default that requires the court to ascertain what individual parties would have wanted. We have analyzed how courts should find the optimal rule within the class of untailored defaults; we now examine whether a tailored default is superior to an untailored default.

With a tailored default the court attempts to determine the default for which the particular parties would have contracted. A major cost of tailored defaults, then, is the cost of this ex post determination. ${ }^{126}$ Instead of having the different types of parties separating themselves into different contractual groups ex ante, the court attempts the separation ex post. Instead of contracting costs, the costs of ex post tailoring are the costs of distinguishing between types of contractual parties, where each type would have contracted for a different rule.

These costs of determining what the particular parties would have contracted for can be significant. For example, in Jordan v. Duff \& Phelps, Inc., ${ }^{127}$ two leading law-and-economics practitioners, Judges Easterbrook and Posner, disagreed about what the particular parties would have wanted. In Jordan the Seventh Gircuit was called on to fill a gap in a shareholder/employment agreement. The court needed to determine whether the defendant corporation had a duty to disclose material information about a merger to an employee who was about to quit and who was, according to the agreement, thereby required to sell his shares. Predictably, both judges agreed that contractual gaps should be filled with terms that the parties would have wanted. ${ }^{128}$

The judges, however, strongly disagreed about what these terms would have been. Judge Easterbrook, authoring the majority opinion, found it "unwarranted to say that the implicit understanding between Jordan and Duff \& Phelps should be treated as if it had such a no-duty clause; we are

the costs of contracting around it are low $\left(\mathrm{C}_{\mathrm{xj}} \simeq 0\right.$, for all $\left.\mathrm{j}\right)$.

For example, consider our earlier discussion of the zero-quantity default, supra text accompanying notes $42-46$. The default choice is non-dichotomous. Numerous quantities could be chosen as the default. Although contracting parties would not contract to exchange zero quantity $\left(x_{0}=0\right)$, most people contract around this default, and the costs of contracting around it are low.

125. Any untailored quantity default would be, except for the smallest proportion of transactions, a penalty default. For example, only the smallest percentage of contracting parties would actually want a default quantity of some randomly chosen number such as, say, 39 or 2003.

126. Richard Epstein criticizes Judge Posner's analysis in EVRA Corp. v. Swiss Bank Corp., 673 F.2d 951, 954 (7th Cir. 1982), because contributory negligence requires costly ex post tailoring by courts. Epstein, supra note 64, at 134.

127. 815 F.2d 429 (7th Cir. 1987).

128. Id. at 436; id. at 446-47 (Posner, J., dissenting). 
not confident that this is the clause firms and their employees regularly would prefer."128

Judge Posner, in dissent, argued that the parties would have waived any duty of disclosure because waiving such a duty would have "aligned their respective self-interests better than the legal protection that the court devises today." ${ }^{130}$ This disagreement between sophisticated jurists suggests that tailoring costs include not only the out-of-pocket litigation expenses but also the potential costs of judicial error. Indeed, if the expected costs of ex post tailoring are sufficiently large, even a tailored rule may give the parties an incentive to contract explicitly ex ante. Ex post tailoring may be more expensive to contracting parties than ex ante contracting. Even if judicial tailoring is accomplished without error, parties may prefer to contract for the same terms that the courts would provide at a higher cost ex post. ${ }^{131}$

But these costs of distinguishing between different types of parties are not the only costs of tailored rules. Because courts do their tailoring after the fact, tailored rules can actually exacerbate the inefficiency of strategic incompleteness. With a tailored rule the relatively informed party-assured that the court will provide the terms that fully-informed parties would want-may have no incentive to reveal her private information to the other party. For example, in our Hadley model the highdamage rule was a tailored default that gave each contracting type what they would have contracted for were they fully informed-damages of $D_{H}$ or $D_{L}$, depending on the miller's type. Yet, we have shown conditions under which this tailored high-damage default gives rise to the costs of inefficient reliance or precaution. ${ }^{132}$ By not explicitly contracting for damages ex ante, the carrier cannot know if the miller is high-damage or lowdamage and therefore may not choose the correct level of precaution. Even if it is costless ex post for the court to determine exactly what two specific parties would have agreed to ex ante, tailored defaults may not be optimal.

In sum, finding the efficient default can involve a complicated inquiry. Knowledgeable parties can leave holes in contracts for strategic reasons-they might prefer to remain in an undifferentiated pool than pay their full freight in an efficient but unsubsidized equilibrium. Efficiencyminded lawmakers must therefore be attuned to the sources of contractual incompleteness and to the attendant costs of pooling and separating associated with their default choice.

129. Id. at 436 .

130. Id. at 448 (Posner, J., dissenting).

131. This point inverts Posner's observation that it may sometimes be "cheaper for the court to 'draft' the contractual term necessary to deal with the contingency if and when it occurs." $R$. POSNER, supra note 2 , at 82 .

132. See supra text accompanying notes 95-103. 


\section{A TheORY OF Gaps}

The preceding sections have attempted to develop a theory for choosing default rules. But before implementing any default standard, courts need to establish, as a logically prior matter, rules for deciding when a contract is incomplete. ${ }^{133}$ Indeed, the litigants in many cases will argue not only about how the gap should be filled but also about whether there is a gap at all. ${ }^{134}$

For example, returning again to Jordan v. Duff $\mathcal{S}^{2}$ Phelps, ${ }^{135}$ Judges Easterbrook and Posner disagree not only on how to fill a gap in the employment-stockholding contract but also, and more fundamentally, on whether there was a gap to be filled. ${ }^{136}$ Easterbrook's majority opinion concludes that although the fiduciary duty to disclose material information could be contracted around, the parties' agreement did not sufficiently negate this duty: "[T]he possibility that a firm could negotiate around the fiduciary duty does not assist Duff \& Phelps; it did not obtain such an agreement, express or implied." ${ }^{137}$ Easterbrook's decision then proceeds to fill this disclosure gap with the fiduciary duty default. Posner, in dissent, finds that the "stockholder agreement that defined [the employee's] rights as a shareholder "with greater specificity" "138 sufficiently contracted around any default fiduciary duty: "The arrangement that resulted (call it 'shareholder at will') is incompatible with an inference that Duff and Phelps undertook to keep him abreast of developments affecting the value of the firm."139 In Jordan, then, two prominent legal economists disagreed not only about how the gap should be filled but also about what constitutes a gap.

133. At an even more basic level, courts will not be able to determine whether a contract has gaps without a prior theory of contract formation. In general, courts will need to determine:

1) whether the parties have formed a contract,

2) whether the contract has gaps, and

3) how the gaps should be filled.

We implicitly assumed in Sections I and II that there were sufficient objective indicia of the parties' meeting of the minds to infer contractual formation. See Barnett, A Consent Theory of Contract, 86 Colum. L. REv. 269 (1986) (discussing competing theories of contractual formation). This Section's focus on legal formalities should inform courts' theories of contractual formation and contractual gaps.

134. This point is also made in M. Freed \& D. Polsby, Hard Cases Make Bad Law: Employment at Will at the Edge (1988) (unpublished manuscript on file with authors). For example, Freed and Polsby criticize Richard Epstein's analysis, see Epstein, supra note 120, at 980, that the court supplied the correct "gap-filling" default in Coleman v. Graybar Elec. Co., 195 F.2d 374 (5th Cir. 1952), an employment at will/wrongful termination case: "The contract in Graybar was anything but silent ... . Such an agreement could hardly 'provide otherwise' with more clarity, short of specifically reserving the employer's right to act in bad faith." M. Freed \& D. Polsby, supra, at 2.

135. 815 F.2d 429 (7th Cir. 1987); see supra text accompanying notes 127-31.

136. Judge Posner argued in the alternative. Although he concluded that the contract did not have a gap, id. at 449 (Posner, J., dissenting) ("the parties were not silent"), he alternatively found that even if there were a gap, it should be filled differently than the way Easterbrook recommended. See supra text accompanying note 129.

137. 815 F.2d at 436 .

138. Id. at 447 (Posner, J., dissenting) (quoting majority).

139. Id. 
This question of when a contract is incomplete is identical to the question of what is sufficient to contract around a default. A court's holding that the parties' attempt to contract around a given default is insufficient is identical to a holding that there is still a gap in the contract. By answering one question, the courts necessarily answer the other. Courts need to develop a theory of gaps before they can address how best to fill them.

If the academy has been remiss in developing a theory of default choice, then to an even greater degree it has failed to address what the necessary and sufficient conditions for contracting around defaults should be. In determining these conditions, courts are determining the costs of contracting around a given default. ${ }^{140}$ The received wisdom that transaction costs are responsible for contractual incompleteness implicitly suggests that lawmakers should minimize the costs of contracting around defaults so that if any contracting parties do not like the off-the-rack standard, they can inexpensively tailor their corporate or contractual structure to suit themselves.

But legal rules evince a greater diversity than this simple theory suggests. ${ }^{141}$ Parties wishing to contract around both statutory and commonlaw defaults will encounter varying degrees of difficulty. For example, many sections of the U.C.C. establish defaults that are in force "unless otherwise agreed,"142 but $\S 2-206$ provides that contractual offers shall be construed as inviting any reasonable manner of acceptance "[u]nless otherwise unambiguously indicated,"143 and the Official Comment punctuates this point by saying that this default obtains "unless the offeror has made quite clear that it will not be acceptable."144

Similarly, in the corporate context the common law of promoter liability requires extraordinary efforts to negate the joint and several liability default. For example, in Stanley J. How $\mathcal{E}$ Assocs. v. Boss, ${ }^{145}$ a promoter was held liable under a contract even though he signed the preincorporation agreement: "By: Edwin A. Boss, Agent for a Minnesota Corporation to be formed, who will be the Obligor."146 The court held that "[w]hile the agreement was not completely clear, the words "who will be the obligor' are not enough to offset the rule that the person signing for the nonexistent corporation is normally to be personally liable."147 Con-

140. These costs were represented as $c_{\mathrm{i}}$ in the early model of default choice. See supra Section II.

141. But see Black, supra note 1 (arguing that corporate default rules are trivial). Black's arguments imply that corporate formalities do not impede corporations from establishing tailored forms of corporate governance. But the costs of contracting around some "strong" defaults (that is, fulfilling certain corporate formalities) are likely to give some formalities a more substantive or nontrivial nature. See, e.g., infra notes 148-50.

142. See, e.g., U.C.C. § 2-303 (1976).

143. U.C.C. $\$ 2-206$ (1976) (emphasis added).

144. Id. at Official Comment 1 (emphasis added).

145. 222 F. Supp. 936 (S.D. Iowa 1963).

146. Id. at 939 .

147. Id. at 942 . The holding is consistent with the common-law doctrine of construing contractual 
tracting around corporate statutes especially exhibits different degrees of difficulty. For example, certain default rules of corporate governance can be changed only in the articles of incorporation, while others can be overcome through less costly bylaw amendments. ${ }^{148}$

At times even seemingly immutable rules can be circumvented at a cost. To be sure, some methods of contracting around legal rules are better described as examples of abuse of the law. ${ }^{149}$ But lawmakers at other times seem to allow ostensibly immutable rules to be negated if the private parties structure the transaction properly. For example, the seemingly immutable rule that limited partnerships must have at least one general partner (that is, one partner who retains unlimited personal liability) can be contractually negated in jurisdictions that allow corporate persons to serve as the sole general partner. ${ }^{150}$

\section{A. Peevyhouse and the Default-Immutable Spectrum}

As the cost of contracting around a default rule becomes extremely large, the default starts to look like an immutable rule. ${ }^{181}$ The Oklahoma Supreme Court's classic decision in Peevyhouse v. Garland Coal \& Mining $\mathrm{Co}^{162}$ exemplifies this insight. The Peevyhouses leased their land contemplating that it would be strip-mined. The contract included specific covenants that Garland would restore the land at the end of the lease

ambiguities against the drafter. See supra note 82 .

148. Defaults that may be contracted around only in the articles of incorporation include: Board of directors may be dispensed with entirely in limited circumstances or its functions may be restricted, Revised Model Business CoRP. ACt ANN. $§ 8.01$ (1984); power to compensate directors may be restricted or eliminated, REvised MODEL Business CoRP. ACT ANN. $\$ 8.11$ (1984); special voting groups of shareholders may be authorized, REvised Model Business CoRP. ACT ANN. $\$ 7.25$ (1987); and classes of shares may be given more or less than one vote per share, Revised MODEL Business CORP. ACT ANN. $\$ 7.21$ (1987). Defaults that may be contracted around in either the articles of incorporation or the bylaws include: Number of directors may be fixed or changed within limits, Revised Model Business Corp. ACT ANN. $\$ 8.03$ (1987); qualifications for directors may be prescribed, Revised MOdel. Business CORP. ACT ANN. $\S 8.02$ (1987); shares may be issued without certificates, REvised Model. Business CoRp. ACT ANN. \$ 6.26 (1987); power of board of directors to amend bylaws may be restricted, REvised MODEL Business CORP. ACT ANN. $\$ \$ 10.20$, 10.22 (1987). See Revised Model Business CoRp. ACT ANN. $\S 2.02$ official comment.

149. The field of tax abounds with instances in which clever citizens abusively attempt to contract around tax liabilities in ways that Congress did not foresee or intend. See, e.g., Heintz v. Comm'r, 25 T.C. 132 (1955) (stockholder of merging corporation contractually abrogates seemingly immutable rule for capital gains realization rules); Zuckman v. United States, 524 F.2d 729 (Ct. Cl. 1975) (stockholders of corporation contractually abrogate seemingly immutable rules to carry through losses).

150. In Delaney v. Fidelity Lease Ltd., 526 S.W.2d 543 (Tex. 1975), the Texas Supreme Court voided this contractual attempt to circumvent the general-partner personal-liability rule. The Texas legislature, however, amended its corporations statute to permit a corporation "[t]o be an organizer, partner, member, associate, or manager of any partnership. . . . TEX. Bus. CoRP. ACT ANN. art. $2.02 \mathrm{~A}(18)$ (Vernon 1989).

151. Conversely, if we admit the possibility of lobbying to change current law, even immutable rules are really defaults where the costs of lobbying to change them are prohibitively expensive. This point was made by Joseph Grundfest at the Columbia conference on December 9-10, 1988, supra note 13.

152. 382 P.2d 109 (Okla. 1962), cert. denied, 375 U.S. 906 (1963). 
period. As it turned out, the restoration "would involve the moving of many thousands of cubic yards of dirt, at a cost estimated by expert witnesses at about $\$ 29,000.00$."153 Garland introduced evidence that such restoration would increase the market value of the land by only $\$ 300 .{ }^{154}$ The court was asked to choose the proper measure of damages: cost of performance $(\$ 29,000)$ or diminution in value $(\$ 300)$.

The majority opinion, which limited the Peevyhouses' damages to diminution in value, clearly claimed that the court's ruling could be contracted around.

It should be noted that the rule as stated does not interfere with the property owner's right to "do what he will with his own," or his right, if he chooses, to contract for "improvements" which will actually have the effect of reducing his property's value. Where such result is in fact contemplated by the parties, and is a main or principal purpose of those contracting, it would seem that the measure of damages for breach would ordinarily be the cost of performance. ${ }^{185}$

This passage seems to emphasize that, notwithstanding the holding in this particular case, parties retain the right to contract around the diminutionin-value default standard.

The dissenting opinion, however, points to the specific provisions of the contract that had been added to the usual covenants of the defendant's coal mining leases and that seemed to place the duty of restoration on the defendant. In the face of these contractual provisions, the reader of Peevyhouse is left with two alternative interpretations. Either the majority opinion is 1) disingenuously creating an immutable rule; or 2) creating a "strong" default rule (that the Peevyhouses' amendments did not sufficiently override). ${ }^{156}$ The most straightforward way to distinguish between these competing interpretations is to ask what extra words the Peevyhouses could have added to the contract to "reverse" the majority's

153. Id. at 111 .

154. Many commentators have criticized the majority's opinion for ignoring the subjective (nonmarket) value of the land to the Peevyhouses. See, e.g., Muris, Cost of Completion or Diminution in Market Value: The Relevance of Subjective Value, 12 J. LEGAL STud. 379 (1983) (arguing that courts must recognize subjective value to fill compensatory goal of contract law). However, the courts' reliance on market value is probably more a function of the plaintiffs' trial strategy. The Peevyhouses, in trying to focus the jury's attention on cost of performance, may have strategically decided not to introduce any evidence of subjective value. And the court's opinion seems to indicate that evidence of subjective value should be included in diminution damages: "After a careful search of the record, we have found no evidence of a higher figure [than the $\$ 300$ market diminution], and plaintiffs do not argue in their briefs that a greater diminution in value was sustained." Peevyhouse, 382 P.2d at 114. One would predict that in subsequent litigation plaintiffs would begin to introduce subjective value evidence that would be included in diminution damages.

155. Peevyhouse, 382 P.2d at 114 (citations omitted).

156. The majority's own use of the word "ordinarily" in the last quoted sentence seems to add some support for the immutability interpretation. After all, is the court suggesting that even if the parties explicitly attempt to contract for cost of performance, there still may be "extraordinary" situations in which the diminution in value standard will apply? 
default. If the majority is really doing what it says, we should be able to write such a contract. If we cannot confidently determine what such a contract would need to say, the alternative hypothesis-that Peevyhouse really is creating an immutable rule-becomes more compelling. ${ }^{157}$

While the Peevyhouse opinion has been criticized for reaching the wrong result, ${ }^{158}$ this analysis suggests that the majority also erred by not more clearly establishing what words would be sufficient to contract for the cost of performance damages. Even though the decision (rightly or wrongly) resolved uncertainty about what the default damages would be, it did little to resolve the uncertainty about how one could contract around this default. Even prospective parties who had read Peevyhouse and had known that it "does not interfere with the property owner's right to 'do what he will with his own" "158 would still face considerable uncertainty about how to exercise that right.

This discussion suggests that in many instances decisions should do more than merely decide what the efficient default should be; they should establish "safeharbors" of contractual language that will be sufficient to reach other contractual outcomes. ${ }^{180}$ As the Peevyhouse case illustrates, by giving prospective parties examples of explicit language, courts can dramatically reduce the uncertainty and costs of contracting around the specific default. ${ }^{161}$

\section{B. Determining the Efficient Level of Legal Formalities}

There can be good economic reasons for "strong" defaults in which the courts intentionally increase the procedural costs to parties of contracting around the default. These reasons parallel the rationales given in one of the first intuitively economic analyses of contract law, Lon Fuller's classic, Consideration and Form. ${ }^{162}$ Fuller suggested that legal formalities serve

157. Tracking the majority's language, we suggest that prospective parties attempting to overcome the diminution-in-value standard include the following covenant:

The parties specifically intend and contemplate that the lessee shall restore the land, even if the costs of performance are grossly disproportionate to the diminution in value from failing to restore the land. This is a main and principal purpose of the lease. In writing this provision, we are explicitly contracting around the holding of Peetyhouse v. Garland Coal.

If this provision were not sufficient, the Peevyhouse rule would, in fact, be immutable.

158. See, e.g., Birmingham, Damage Measures and Economic Rationality: The Geometry of Contract Law, 1969 DukE L.J. 49.

159. Peeryhouse, 382 P.2d at 114.

160. Courts may face the constitutional limitation of resolving only "cases or controversies" at issue. U.S. CoNST. art. III, $\S 2$, cl. 1. But other decisions have established prospective safeharbors. See, e.g., Miranda v. Arizona, 384 U.S. 436 (1966) (establishing fair and effective warning requirement to persons in police custody).

161. The purpose of such contractual safeharbors should not be to preclude the parties from tailoring other standards. The safeharbor alternatives might additionally provide benefits as common-law interpretations would more fully specify their meanings. See J. Gordon, supra note 13

162. Fuller, Consideration and Form, 41 ColuM. L. Rev. 799 (1941). In truth, the fact that the article is claimed by economists (it is, for example, reprinted in A. Kronman \& R. Posner, The ECONOMics of ConTract Law 40 (1979)) is as much a tribute to the soundness of its insights as to its nexus with economics. 
evidentiary, cautionary and channelling functions. The necessary and sufficient conditions for contracting around a default are examples of formalities that courts require. Our discussion accordingly tracks Fuller's categories.

In Fuller's analysis, the evidentiary function of legal formalities is to provide information to courts in order to lower the costs of subsequent decision making. This analysis is quite resonant with our earlier conclusion that penalty defaults could be justified on efficiency grounds as ways of encouraging the revelation of information. ${ }^{163}$ In choosing the necessary conditions (the formalities) for contracting around a default, a court should consider similar informational aspects. We go beyond Fuller though and argue that the evidentiary function of legal formalities can serve to inform not only the courts but the parties within the contract as well. ${ }^{164}$ For example, if a penalty default is chosen to encourage one party to reveal information to another, the court may want to regulate the process of contracting around the default so that meaningful information is conveyed.

Structuring formalities to facilitate internal information flows is also related to the cautionary function of legal formalities. Fuller argues that some formalities, such as certain writing requirements, serve a cautionary function by forcing the parties to undertake a minimal amount of reflection before being bound by a contract. But, as already discussed, when the parties to a contract have disparate amounts of information, lawmakers may want to establish formalities that are more directed toward protecting the relatively uninformed. For example, a holding contrary to Peevyhouse, in which the courts not only choose cost-of-performance damages as the default but also require extremely explicit language to opt for value diminution damages, might be justified to caution the relatively uninformed landholders of their legal rights. ${ }^{165}$ To caution is to give information. Attention to how legal formalities will affect the flow of information should inform lawmakers' theory of gaps as well as their theory of default choice.

Finally, Fuller suggested that legal formalities could serve a chanelling function which, for example, would allow parties to channel their contractual agreements toward legal or non-legal enforcement. Fuller's theory of channelling is highly analogous to our earlier discussion of pooling and especially separating equilibria. ${ }^{166}$ As we discussed in our Hadley model,

163. See supra text accompanying notes $47-60$.

164. See supra text accompanying notes 53-60.

165. Similarly, if strategic withholding of information explains why employers do not reveal to employees the true probability of future termination, employees may make inefficient investments in goods such as housing and human capital. In such situations it may be efficient for courts not only to make a default rule against termination without cause but also to require employers to state specifically that they wish to be able to fire for even arbitrary reasons. But see Epstein, supra note 120 (arguing against such a rule); M. Freed \& D. Polsby, supra note 134

166. See supra text accompanying notes 111-14. 
different defaults can lead to different degrees of separation. ${ }^{167}$ As with chanelling, the separating effect of legal defaults may allow parties to sort themselves into different groups.

There may be situations in which courts should increase the costs of contracting around defaults to force the majority of parties into a particular channel. For example, if a certain type of contract generates a mild externality, we may want to discourage most people from entering this type of contract. But if there is a small class of contracting parties that will be damaged more than society gains if they fail to contract, then courts may want to consider a method of "chanelling" or "separating" the socially beneficial from the deleterious classes of transactions.

One way to do this would be by direct fiat, but there may be ways of encouraging the parties to sort themselves into the correct categories through legal rules. For example, by artificially increasing the costs of contracting around a no-contract default, courts may discourage the lowbenefit contractors but not the high-benefit contractors. Although such legal formalisms may engender the efficient types of contracting, they may still be inefficient because the additional transaction costs that the formalities engender are a social cost that could be avoided by simply imposing a tax of an equal magnitude. The tax would be a transfer to the government instead of a dead-weight loss. If courts are constrained from imposing taxes, ${ }^{\mathbf{1 6 8}}$ however, intentionally costly formalisms that increase the cost of contracting around "strong" defaults may be the most efficient rules within their choice set. The channelling function of legal formalities can also be given an informational justification because the very process of self-sorting reveals information about the parties' preferences. ${ }^{168}$

Such intentionally costly formalism would not be used in conjunction with a penalty default. Since the whole point of penalty defaults is to encourage parties to contract around them, formalisms that increase the cost of doing so would be counterproductive. In essence, penalty defaults encourage, and "strong" defaults discourage, contractual mutation.

\section{Legal Responses to Contracting Around Immutable Rules}

An important difference between default and immutable rules is that if parties attempt to contract around a default rule and fail, they will simply

167. See supra text accompanying notes 114-16.

168. See, e.g., I. Ayres \& P. Schmitt, Court-Ordered Funding of School Desegregation Remedies: Federalism Versus Minority Rights $\$ 3$ (1989) (unpublished manuscript on file with authors) (discussing constitutional limits on judicially imposed taxation).

169. The possibility that courts may intentionally want to increase the costs of contracting around a default might potentially explain their refusal to articulate alternative safeharbors. If there is uncertainty about what is sufficient to overcome a particular default, the parties will be discouraged ex ante from even trying. This argument might provide an apology for the Peevyhouse holding. However, in Peevyhouse the societal externalities of strip-mining militate toward a cost-of-performance default. This channeling explanation is therefore inapposite to the Peevyhouse fact pattern. 
be bound by the default, whereas if parties attempt to contract around an immutable rule and fail, the law may choose to penalize the attempt by imposing a penalty different from (and, from the parties' ex ante perspectives, worse than) the immutable standard. From an ex ante perspective the possibility of receiving this ex post penalty is just another expected cost of contracting around the default rule.

The legal response to parties who try to contract around immutable rules can also be given a default interpretation. In these cases the courts remove the clauses that transgress the immutable rule and then choose a default to fill the gap. For example, in Frostifresh Corp. v. Reynoso, ${ }^{170}$ the trial court established an immutable rule that retailers cannot sell at unconscionably high markups. Accordingly, the court struck out the contract's price provision (which was more than three times the retailer's cost), but it then had to decide how to fill the gap. The trial court decided that the reconstructed contract should have a price which only covered the seller's cost. The appellate court reversed and awarded the seller "a reasonable profit" instead of zero profit. ${ }^{171}$ The difference in these holdings is very similar to the tension between a tailored default and penalty default. Reconstructing the contract to give the seller a reasonable profit is identical to the U.C.C.'s reasonable-price standard. The zero-profit standard is analogous to a penalty default, in this case imposing the penalty on the seller for trying to contract around a rule, while the penalty defaults discussed earlier penalize parties for not contracting around the rule.

This same tension arises with covenants not to compete. Courts have established an immutable rule that parties cannot make covenants of unreasonable duration. In Fullerton Lumber Co. v. Torborg, ${ }^{172}$ for example, the Supreme Court of Wisconsin held that a ten-year covenant was unreasonable but then struggled in deciding whether it should reformulate the contract to impose a duty not to compete for a reasonable period or penalize the employer for transgressing the immutable limitation by allowing the former employee to compete immediately. ${ }^{173}$

If the goal of an immutable rule is to discourage people from even attempting to contract around a provision, then it would seem that the penalty reconstruction would be the favored result. ${ }^{174}$ This is again analogous

170. 52 Misc. 2d 26, 274 N.Y.S.2d 757 (Dist. Ct. 1966), rev'd 54 Misc. 2d 119, 281 N.Y.S.2d 964 (App. Term 1967).

171. Frostifresh Corp. v. Reynoso, 54 Misc. 2d 119, 281 N.Y.S.2d 964 (App. Term 1967).

172. 270 Wis. 133,70 N.W.2d 585 (1955).

173. The majority reconstructed the contract to have a covenant of "reasonable" duration. 270 Wis. at $146-47,70$ N.W.2d at 592 . The dissent would have penalized the employer by allowing the employee to compete immediately. Id. at 148-52, 70 N.W.2d at 593-94 (Gehl, J., dissenting).

174. A penalty for even attempting to contract around a legally immutable provision may be necessary to deter attempts in a world where some disputes are not litigated. If all disputes were litigated, attempts to contract around an immutable rule would never succeed. But if some contractual parties fail to challenge unenforceable immutable rules, then imposing a penalty whenever a case does come to court might be justified to prevent underdeterrence. For example, it is widely believed that 
to our earlier discussion of penalty defaults, in which we suggested that courts should choose the penalty that provided "least cost deterrence."175 The difference is that in the earlier discussion the penalties were attempting to deter gaps and here the penalties are attempting to promote gaps (that is, deter contracting around). The preference for penalty defaults to fill the gaps left in unconscionable contracts may justify the common law "blue pencil" test which simply enforces contracts after the offending provision has been struck (with a blue pencil). ${ }^{176}$

\section{CONCLUSION}

This article has suggested how efficiency-minded lawmakers should go about filling gaps in contracts. The reasons that parties leave gaps in contracts should strongly inform this decision. Our theory of defaults should, in a sense, be guided by our theories of why there are contractual gaps. Prior theorists have argued that parties leave gaps in contracts because the cost of writing additional terms outweighs the benefit. Accordingly, they have suggested that courts should simply fill in the gap with the term the parties "would have wanted."

This article, however, has articulated a second cause of contractual incompleteness. We have shown that when one party to a contract knows more than another, the knowledgeable party may strategically decide not to contract around even an inefficient default. Because the process of contracting around a default can reveal information, the knowledgeable party may purposefully withhold information to get a larger piece of the smaller contractual pie. This possibility of strategic incompleteness leads us to embrace more diverse forms of default rules. In particular, lawmakers may be able to undercut the incentives for this strategic rent-seeking by establishing penalty defaults that encourage the better informed parties to reveal their information by contracting around the default.

Our analysis does not imply that penalty defaults should be used in all contractual settings. The decision by efficiency-minded courts or legislatures to impose a penalty, untailored majoritarian, or tailored "what the parties would have wanted" default in a particular setting is not a trivial one. The first step in the decision-making process should be to ask "why does the gap exist?" We have suggested that parties may fail to contract around inefficient defaults for strategic as well as transaction cost reasons. When parties fail to contract because they want to shift the ex ante trans-

creditors and residential landlords make a practice of including all sorts of illegal clauses in their contracts not because they think the clauses will stand up in court, but because they know that most debtors and tenants have more respect for written contracts than most courts do. The authors are indebted to conversations with Richard Craswell for this point. See Craswell, supra note 22, at 64-65.

175. See supra Section I.B.

176. See Fullerton, 270 Wis. at 43,70 N.W.2d at 590 . The "blue pencil" test is the traditional test of severability. If, after removing the unconscionable terms, the contract is still comprehensible in that the parties might have still entered into it, the court will enforce it. 
action cost to a subsidized ex post court determination, a penalty default of non-enforcement may be appropriate. When strategic considerations cause a more knowledgeable party not to raise issues that could improve contractual efficiency, a default that penalizes the more informed party may encourage the revelation of information. ${ }^{177}$

Lawmakers should not, however, impose penalty defaults indiscriminately. Even if strategic considerations are established as a significant source of contractual incompleteness, courts or legislatures should consider the costs and benefits of penalty defaults themselves. Since the goal of a penalty default is to induce information revelation, lawmakers should consider the likelihood that the penalty will in fact result in information being revealed, ${ }^{\mathbf{1 7 8}}$ the benefit (in more efficient reliance or precaution) of the revealed information, and the costs of explicitly contracting around the default. If the private information is acquired with economic resources, the value of information revelation must also be weighed against the private incentives to acquire it. Penalty defaults are therefore more likely to be efficient if the private information is acquired passively. In sum, a penalty default should be used if it results in valuable information revelation with low transaction costs. ${ }^{179}$

Throughout the discussion we have cited examples of common-law and statutory rules that are broadly consistent with our theory's categories of penalty, tailored and untailored defaults. But we believe that both courts and legislatures should be more sensitive to the process of contracting. Lawmakers should consider explicitly the informational as well as the contractual equilibria generated by alternative default rules. Different defaults may generate different degrees of pooling and separating. When heterogeneous contracting parties separate themselves into different con-

177. In many settings, such as simple contracts for small transactions, it is easy to point to transaction costs as the source of incompleteness. In other settings, however, parties write complicated, lengthy contracts that are carefully considered by both parties and their lawyers. In these situations a contingency that is not contracted for may be sufficiently important that it is unreasonable to ascribe incompleteness to transaction costs. Some omitted clauses, for example, may be very inexpensive to include from a transaction cost perspective, such as liquidated damage clauses or non-refundable deposits. In such cases courts will find it difficult to point to transaction costs as the source of incompleteness, so penalty defaults should be considered.

178. For example, we suggested that Goldberg's zero-damage penalty default would not sufficiently encourage retailers to contract for liquidated damages, and even if a larger penalty would, the amount of liquidated damages in equilibrium might "pcol" at a non-informative low level. See supra Section I.C.2. Courts should also consider the possibility that some parties will fail to contract around penalty defaults out of ignorance or oversight.

179. The Hadley rule is an example of a penalty default that 1) is cheap to contract around by including a liquidated damage clause, 2) will likely cause damage information to be revealed, and 3) will facilitate more efficient precaution.

We must add an important transitional caveat. A legal change from one default to another can be costly-especially if the move is to a penalty default. Until parties become informed about the new default, there may be transitional costs as the parties continue to bargain in the shadow of an invalid law.

Finally, we note that in many contractual settings, both parties may have private information which they choose to withhold. In such settings of "dual asymmetric information," penalty defaults may not be sufficient to ensure that all private information is revealed. 
tractual agreements, they reduce the inefficiencies of strategic pooling but at the cost of increased contracting. Lawmakers need to weigh these costs of pooling and separating in choosing the right rule; but more fundamentally, they need to be able to predict how much pooling and separating different rules are likely to generate.

The analysis of the article is quite general and can be applied to a wide range of legal issues. ${ }^{180}$ For example, courts in interpreting statutes are often called upon to fill gaps. A number of scholars have used a "legislation-as-contract" approach to resolve such questions. ${ }^{181}$ Jon Macey has proposed a type of penalty default by suggesting that statutory gaps be filled with public-regarding legislation. ${ }^{182}$ Macey's default is not what the legislature would have contracted for and thus forces the legislature to make their pork-barrel deals public. Justice Scalia has gone the furthest, however, in articulating a penalty default standard of statutory interpretation. ${ }^{183}$ In Agency Holding Corp. v. Malley-Duff \& Assoc., ${ }^{184}$ the Supreme Court was asked to supply a default statute of limitations for a civil $\mathrm{RICO}^{185}$ action because the legislation was silent on the issue. While the majority established a four-year limitation as what Congress would have wanted, Justice Scalia argued that there should be no statute of limitation. Scalia was "unmoved by the fear that [this] conclusion might prove 'repugnant to the genius of our laws' "'186 and even suggested that this penalty default might encourage Congress to contract around it: "Indeed, it might even prompt Congress to enact a limitations period that it believes 'appropriate,' a judgment far more within its competence than ours."18z Ironically, Justice Scalia is arguing for an extreme form of judicial activism. Only by choosing a default that is wholly at odds with Congressional intent can the Court ensure that Congress will reveal its intent. Scalia's ultimate message then is that extreme activism can become a form of disempowering judicial restraint. Examples such as these underscore our primary thesis that efficient defaults may at times deviate from what the parties would have wanted. More importantly, they demonstrate that our

180. See discussion supra note 10.

181. See Easterbrook, The Supreme Court, 1983 Term-Foreword: The Court and the Economic System, 98 Harv. L. Rev. 4, 15-16 (1984).

182. Macey, Promoting Public-Regarding Legislation through Statutory Interpretation: An Interest Group Model, 86 Colus. L. Rev. 223, 236-40 (1986).

183. For a more general discussion of using penalty defaults to force Congress to enunciate the law, see L. Marshall, Let Congress Do It: The Case For an Absolute Rule of Statutory Stare Decisis (1989) (unpublished manuscript on file with authors).

184. 483 U.S. 143, 157 (1987) (Scalia, J., concurring).

185. Racketeer Influenced and Corrupt Organizations Act (RICO), 18 U.S.C. § 1964 (1982 \& Supp. V 1987).

186. 483 U.S. at 170 (Scalia, J., concurring) (quoting Occidental Life Ins. Co. v. EEOC, 432 U.S. 355 (1977) quoting Adams v. Woods, 6 U.S. (2 Cranch) 336, 342 (1805)).

187. 483 U.S. at 170. 
choice of default must be informed by an understanding of why contracting parties-such as legislatures-leave gaps in their texts. ${ }^{188}$

Finally, we suggest that teachers focus more explicitly on the difference between default and immutable rules. Often students are able to recite the various rules learned in a course without knowing whether they are obligatory or not. Teaching which rules are defaults is not a mere pedagogical conceit. To represent their clients effectively, attorneys need to know not only what the legal rules are, but how, if at all, they can be abrogated to further their clients' interests. ${ }^{188} \mathrm{~A}$ descriptive knowledge of defaults and how to contract around them is a prerequisite of effective advocacy.

188. For example, the statute of limitation gap of RICO in Malley-Duff is hard to explain as hidden pork-barrel legislation.

189. In corporate law especially, the mechanism for contracting around the default may be oblique. For example, while corporate statutes do not give the board of directors the right to disapprove a merger, certain "poison pill" plans have the effect of making the board sign off on any hostile bid. See Dynamics Corp. of Am. v. CTS Corp., 805 F.2d 705 (7th Cir. 1986) (analyzing economic impact of "poison pill"). 